\title{
DiagnOSTIC Utility OF FACET (ZYGAPOPHYSIAL) JOINT INJECTIONS IN Chronic Spinal Pain: A Systematic Review of Evidence
}

\begin{abstract}
Nalini Sehgal, MD, Rinoo V. Shah, MD,
\author{
Nalini Sehgal, MD, Rinoo V. Shah, MD,
}

Background: Chronic refractory spinal pain poses a peculiar diagnostic challenge because of multiple putative pain sources, overlapping clinical features, and nonspecific radiologic findings. Diagnostic injection techniques are employed to isolate the source(s) of pain. Facet or zygapophysial joint pain is an example of spinal pain diagnosed by local anesthetic injections of the facet joint or its nerve supply. Diagnostic facet joint injections are expected to meet the cardinal features of a diagnostic test (i.e., accuracy, safety and reproducibility). Accuracy must be compared with a "gold" or criterion standard that can confirm presence or absence of a disease. There is, however, no available gold standard, such as biopsy, to measure presence or absence of pain. Hence, there is a degree of uncertainty concerning the accuracy of diagnostic facet joint injections.

Objectives: To evaluate accuracy, safety
\end{abstract}

and reproducibility of facet or zygapophysial joint injections in diagnosing chronic spinal pain of facet joint origin.

Study Design: A systematic review of the literature for clinical studies on efficacy and utility of facet joint/nerve injections in diagnosing spinal pain from facet joints.

Methods: Relevant literature on diagnostic facet injections was identified through database searches. Excluded were abstracts, reviews, book chapters, case reports and studies based on single blocks or blocks without radiologic control. Prospective studies with placebo control, or controlled comparative local anesthetic blocks, were given priority over retrospective studies. Each study was graded using AHRQ and QUADAS criteria. The level of evidence was classified as conclusive, strong, moderate, limited, or inconclusive.

Results: Available literature pointed to strong evidence for controlled comparative local anesthetic facet joint medial branch blocks in the diagnosis of neck and low back pain. There was moderate evidence in the diagnosis of pain arising from thoracic facet joints.

Conclusion: The evidence obtained from literature review suggests that controlled comparative local anesthetic blocks of facet joint nerves (medial branch or dorsal ramus) are reproducible, reasonably accurate, and safe. The sensitivity, specificity, false-positive rates, and predictive values of these diagnostic tests for neck and low back pain have been validated and reproduced in multiple studies.

Keywords: Chronic spinal pain, neck pain, low back pain, cervical facet joint, thoracic facet joint, lumbar facet joint, zygapophysial joint, medial branch block, intraarticular injection
Spinal pain is a major cause of chronic pain and disability $(1,2)$. In patients with chronic spinal pain, the prevalence of pain by spinal region has been reported as $44 \%$ for cervical, $56 \%$ for lumbar, and $15 \%$ for the thoracic spine (3, 4). Despite the overall high prevalence of chronic spinal pain, on the basis of the clinical examination, a specific etiology can be established with certainty in only

From: University of Wisconsin Hospital \& Clinics, Madison, WI; International Pain Institute, Texas Tech University, Lubbock, TX; Center for Pain Medicine, Emory Department of Anesthesiology, Emory Center for Pain Medicine, Atlanta, GA; and Department of Orthopaedics; and University of Rochester Medical Center, Rochester, NY,

Address Correspondence: Nalini Sehgal, MD,

E3/268 Clinical Science Center,

600 Highland Avenue, Madison, WI 53792-3228

Disclaimer: Nothing of monetary value was received

in the preparation of this manuscript.

Conflict of Interest: None

Acknowledgement:

Manuscript received on 12/10/2004

Revision submitted on $02 / 21 / 2005$

Accepted for publication on $02 / 26 / 2005$
$15 \%$ of patients (5-9).

A practical approach to the treatment of chronic low back pain requires a specific anatomical diagnosis (9). For an anatomic structure to be deemed a potential cause of back pain it must fulfill four criteria:

1) the structure must have a nerve supply;

2) it should be capable of causing pain similar to that seen clinically in normal volunteers;

3) it must be susceptible to painful diseases or injuries; and

4) using diagnostic techniques of known reliability and validity, the structure must be a demonstrated as a source of pain in patients (10).

Facet joints are a well-recognized source of pain in subjects with persistent spinal pain (10-56). However, there are no specific markers of facet joint pain. Conventional clinical and radiologic tech- niques are unreliable in diagnosing facet or zygapophysial joint pain $(2,9,10,27$ 29, 32-34, 36, 42, 43, 45-70). Controlled local anesthetic blocks of the facet joint or its nerve supply are employed to diagnose facet joint pain. Single uncontrolled facet blocks are compromised by an unacceptably high false-positive rate and low predictive value (27-31, 33-35, 37-41, 44, 7180). Placebo-controlled techniques, considered as the gold standard, have limited clinical utility due to ethical and cost implications. The use of controlled comparative blocks with short and long acting local anesthetics is an acceptable alternative strategy (27-31). The validity and accuracy of these precision diagnostic techniques, however, has been questioned (72$74,80)$.

It is reported that precision diagnostic needle blockade of a structure with a nerve supply, and ability to generate pain, has several advantages over other available diagnostic techniques. It permits testing 
of the hypothesis that a target structure is the source of a patient's pain $(27,45)$. When combined with fluoroscopic guidance, it selectively and accurately accesses targeted spinal structure(s) (e.g., disc, facet joint, or spinal nerve) that are otherwise inaccessible to palpation. Injection of radiopaque contrast dye confirms that the target structure, and only the target structure, has been reached by the needle or by anything injected through it (45). The physiologic response to a block (presence or absence of pain relief) is used to determine whether or not the target structure is painful. Noninvasive imaging studies lack this capability. Finally, by using controlled blocks, the validity of the test can be critically evaluated in each and every patient.

The accuracy of a diagnostic test is determined by assessing specificity and sensitivity. Specificity is a relative measure of the prevalence of false-positives, whereas sensitivity is the relative prevalence of false-negative results. There is no test in clinical medicine that has an ideal $100 \%$ sensitivity and specificity. Consequently, there is a degree of uncertainty regarding the accuracy of each and every diagnostic test as applied to an individual clinical case.

Hildebrandt (73), in an extensive review on the relevance of diagnostic zygapophysial joint blocks, concluded that the diagnostic use of neural blockade rests on three premises:

1) The pathology causing pain is located in an exact peripheral location, and impulses from this site travel via a unique and consistent neural route;

2) Injection of local anesthetic totally abolishes the sensory function of intended nerves and does not affect other nerves; and

3) Relief of pain after local anesthetic block is attributable solely to the block of the target afferent neural pathway.

According to Saal (74), tests used for diagnosing the source of chronic low back pain require accurate determination of the abolition or reproduction of the patient's pain symptoms. He compared precision diagnostic injections to physical examination tests that, unlike most laboratory tests in clinical medicine, do not have an absolute gold standard in the form of a tissue diagnosis to determine their true accuracy. He recommended that rather than concluding these tests as useless or invalid, multiple facts should be considered together with the inaccuracies that are present in all diagnostic tests in medicine.

Bogduk and McGuirk $(9,45,81,82)$ described in detail the accuracy and value of precision diagnostic blocks and proposed an algorithmic approach to diagnosis of chronic low back pain. Manchikanti et al (2), in an evidence-based evaluation of diagnostic interventional techniques provided strong affirmation of the validity, specificity, and sensitivity of facet joint nerve blocks in the diagnosis of spinal pain of facet joint origin. Boswell et al (28) in a systematic review reported the accuracy of precision diagnostic blocks in the diagnosis of chronic spinal pain of facet joint origin. They reported the diagnostic accuracy of controlled local anesthetic facet joint blocks as high.

In contrast, Nachemson and Vingård (83), in assessment of patients with neck and back pain, concluded that various studies employed outside imaging have rarely demonstrated clinical utility. Ramsey et al (84) found that diagnostic and treatment devices that lacked scientific rigor included facet blocks, discography and diagnostic nerve root infiltration, along with electromyogram, stress radiographs and flexion and extension $\mathrm{x}$-rays, bone scintigraphy, thermography, diagnostic ultrasound, and temporary external fixation. North et al (71) reported a limited role for uncontrolled local anesthetic blocks in the diagnostic evaluation of sciatica and referred pain syndromes in general. They also noted that negative blocks are a pattern of responses that may have some predictive value, but isolated, uncontrolled positive blocks are non-specific.

It is suggested that these reported disadvantages can be overcome by applying International Association for the Study of Pain (IASP) criteria (85) and using controlled diagnostic blocks. Face validity of facet joint blocks has been demonstrated (86-88). Construct validity is maintained by the use of comparative local anesthetic blocks, on two separate occasions, when the same joint is anesthetized using two local anesthetics with different duration of action (30-44, 75-79, 89-91).

This systematic review was undertaken to determine the accuracy of facet joint blocks in diagnosing chronic spinal pain.

\section{Methods}

\section{Search Strategy}

A computerized database search was performed of MEDLINE (January 1966November 2004), OVID Current Contents, CINAHL, OVID PreMedline, Cochrane Database of Systematic Reviews, PUBMED, BioMedCentral, and EMBASE. The search included manual searches of bibliographies of systematic and narrative reviews and cross references to the reviews. Keywords used in the search were: Facet joint/ zygapophysial joints as causes of neck/back pain; facet joint/diagnostic injections; diagnostic joint and nerve injections.

\section{Inclusion Criteria}

\section{Type of studies}

All prospective and retrospective studies on diagnostic facet joint/nerve injection were selected for review. In grading the evidence, randomized, doubleblinded, and prospective studies were given priority over retrospective studies.

\section{Types of participants}

Subjects experiencing more than three months of chronic spinal pain of sufficiently severe intensity to warrant further investigations or justify referral to pain/spine specialist, and who had failed adequate trial of conservative management with medications, physical therapy, psychological interventions.

\section{Types of Interventions}

Double block comparative controlled or placebo-controlled studies.

\section{Types of Outcomes}

The criterion standard for diagnosis of facet joint pain was $>50 \%$ pain relief and the ability to perform previously painful maneuvers following joint/medial branch blocks.

\section{Exclusion criteria}

\section{Type of studies}

Studies not meeting inclusion/ exclusion criteria, appropriate outcomes and statistical analysis; articles reporting animal, cadaver, autopsy studies; biomechanical and imaging studies; case reports, book chapters, reviews, guidelines, and expert opinions.

\section{Types of participants}

Subjects with pain duration of $<3$ months and asymptomatic / normal volunteers. 


\section{Types of Interventions:}

1) Single block studies (i.e., facet joint or nerve injections without comparative control or placebo control).

2) Studies without radiologic guidance.

3) Studies describing an injection technique.

4) Pain mapping studies.

5) Studies reporting therapeutic facet joint procedures (i.e., medial branch blocks, radiofrequency neurotomy or intraarticular steroid injections).

\section{Method of Review}

Abstracts obtained from computerized database searches were initially screened for exclusion criteria. Relevant articles were evaluated according to Agency for Healthcare Research and Quality (AHRQ) criteria (92) (Appendix A and B) and QUADAS criteria (Appendix C). Articles were included if they fulfilled at least three of five AHRQ criteria and/or seven of 14 QUADAS criteria for individual articles.

The following data was extracted and tabulated: principal author, study design, number of subjects at enrollment and (where available) final analysis, inclusionexclusion criteria, subject characteristics, interventions, outcome measures, follow up interval, statistical analysis and results. Finally three physician reviewers reviewed selected studies for methodologic quality and grading of evidence.

\section{RESULTS}

Database search yielded 150 relevant articles on facet/zygapophysial joints. A database article log was created, each article was reviewed for inclusion or exclusion criteria, and reasons for exclusion documented in the article log. Thirty-seven studies (30-44, 51, 56, 67-70, 75-79, 9496, 98-105) were selected for review and abstracting. Of these studies, three were clinical outcome studies (94-96), one study evaluated combined disc and facet joint pain (101), one was a subgroup analysis of subjects from two previous studies (102), and one was a retrospective evaluation (105). Two studies evaluated the effect of conscious sedation as a confounding factor $(99,100)$, and one study (98) evaluated the influence of psychological factors on the diagnostic ability of controlled local anesthetic blocks.

\section{Study Design}

There were 10 randomized trials ( 30 , $31,42,43,51,68,69,75,99,100)$ and 17 prospective studies (32-41, 44, 76-78, 98, $103,104)$. Seven studies were randomized, double blind $(30,42,68,69,75,99,100)$ and four were placebo-controlled, double blind studies $(31,43,99,100)$. An independent observer randomly examined every fifth patient in two prospective studies $(32,51)$. Accurate needle placement was confirmed prior to local anesthetic injection by independent observers in four studies $(30,31,43,75)$, and in one study an independent observer graded pain relief (104). Confounding factors were evaluated in three controlled studies (98-100) and long-term validity of lumbar facet diagnosis was reported in one study (97). Five studies evaluated validity of diagnostic blocks $(30,31,86-88)$. Seventeen studies $(32-44,76-78,105)$ reported prevalence of facet joint pain and 14 studies (33-35, 37-41, 44, 75-79) reported false-positive rates of single diagnostic facet blocks.

\section{Subject Enrollment and Dropouts}

There were less than 100 subjects enrolled in 13 studies $(30,31,36,41-43,68$, $75,97,101,103-105), 100-200$ subjects in 14 studies $(32-34,37,39,42,51,69,76-78$, 98-100), and $>500$ subjects in one study (40). Seven studies reported dropouts (36, $42,43,69,97,101,105), 13$ studies reported no dropouts (33-35, 37-41, 44, 75, 98 $100)$, and other studies did not mention dropouts.

\section{Setting and Location}

Seventeen studies were conducted in private practice settings: interventional pain management, spine, radiology or physical medicine and rehabilitation practice, and three studies were reported from a university/tertiary referral center in Australia. Other specialists or practitioners referred subjects for further workup and/or treatments to these practices or centers.

\section{Spine Region Studied}

Ten studies assessed subjects for cervical facet pain $(30,31,39,40,42-44,75$, 99, 105), two studies reported prevalence of pain from thoracic facets $(40,41)$, and 17 studies evaluated lumbar facets in subjects with low back pain (32-40, 51, 76-79, $98,100,104)$. One study (102) performed subgroup analysis, and one (79) was a sta- tistical analysis of subjects from a previous study. Three studies (38-40) reported on prevalence of pain in more than one spine region.

\section{Inclusion Criteria}

Pain duration of more than three months was a consistent inclusion criterion across all studies. Other criteria varied by study. There were multiple studies that enrolled subjects with pain onset following injury at work, motor vehicle accident (MVA), or other injury. Multiple studies included subjects with prior lumbar spine surgery, and some studies included psychological assessments. Twelve studies analyzed clinical features for predicting response to cervical or lumbar facet joint injections $(32-36,43,51,67-70$, 75). Also reported were the influences of age (76), smoking (62), obesity (78), prior surgery (77), psychological comorbidities $(98)$, and sedation $(99,100)$ on the prevalence of facet joint pain and diagnostic validity of facet joint injections.

\section{Interventions}

Except for three studies, all of the studies reviewed utilized double diagnostic blocks with lidocaine and bupivacaine to diagnose facet joint pain. There were two studies that employed placebo-controlled triple blocks $(31,43)$, and one study randomized subjects to intraarticular normal saline or lignocaine injections (68). The interval between first and second (and third) block was usually two or more weeks except in two studies where the interval was one week (32, $43)$. One study did not specify this interval (69). Each study described the method or algorithm, employed to determine the levels and/or sequence of injections. Two studies reported the number of injections performed to identify a positive joint $(75,105)$. In four studies, other diagnostic procedures were performed on the same day as the initial blocks $(32,51,69$, 101). The physician performing the procedure was masked in four studies (31, $43,68,75)$. Two studies evaluated each block for unsuccessful technique and repeated unsuccessful blocks on another day $(30,75)$.

Small volumes of local anesthetics within the recommended range were employed for intraarticular or medial branch blocks. Most studies used lidocaine for the first set of injections and reserved bupivacaine for the second injection in lidocaine 
positive joints. There were five studies that injected lidocaine and bupivacaine in random sequence $(30,31,43,69,75)$. In several studies steroids and Sarapin were added as adjuvant(s). Use of mild intravenous sedation with midazolam and fentanyl was reported in some studies.

\section{Measurements/Outcomes}

Analgesic response to local anesthetic injection was the primary outcome measure. Pain scores were recorded on visual analog scale (VAS) or numeric pain rating scale (NPS) before the procedure and after the procedure. All but one article (103) described the degree of pain relief either as a percentage or graded from worse to complete pain relief. The criterion for second (confirmatory) block varied from $>50 \%$ pain relief to complete abolition of pain. The criterion used for diagnosis of facet joint pain was significant pain relief ( $50 \%$ to complete relief) for the duration of anesthetic used ( $>45$ minutes to $>2$ hours with Lidocaine and $>2$ 3 hours with Bupivacaine), and pain relief from bupivacaine lasting beyond that obtained from lidocaine, and/or ability to perform prior painful movements.

There was one study that determined diagnostic significance of pain provocation response and graded the evoked pain response from unfamiliar to exact pain (104). Four studies $(34,51,69,70)$ determined predictive value of previously reported clinical criteria for facet joint pain.

\section{Statistical Analysis}

Commonly used statistical tests consisted of Chi-square test, frequency and contingency tables, 95\% confidence interval analysis for prevalence, sensitivity, specificity, predictive values and likelihood ratios. Two studies provided tables for determining positive and negative predictive values for single blocks (75, 79) and controlled blocks (75) at varying prevalence or pretest possibilities. Statistical significance was determined by using $P$ values of $<0.05$. Some studies employed additional tests such as Fisher's exact test, ANOVA, Student's T test, Regression analysis, Kappa and sample size calculation.

\section{Validity}

Medial branch blocks have been shown to maintain face validity. Local anesthetic injected accurately onto the correct target points selectively infiltrates the target nerve, and does not anesthetize any adjacent structures that might be an alternative source of pain to the zygapophysial joint $(86,87)$. In addition, medial branch blocks have been shown to protect normal volunteers from pain provoked experimentally from the anesthetized joint (88).

Medial branch blocks have been shown to demonstrate construct validity. However, to have construct validity, medial branch blocks must be controlled. Single diagnostic blocks carry a false-positive rate of $27 \%-63 \%$ in cervical spine, $55 \%$ $58 \%$ in the thoracic spine, and $17 \%-47 \%$ in lumbar spine $(27,28,33-35,37-41,44$, 75-79). Patients may report relief of pain after a diagnostic block for reasons other than the pharmacologic action of drug administered (30). Thus, it is essential to know the true positive response in every individual case. The validity of controlled comparative local anesthetic blocks for facet joint diagnostic blocks was confirmed with placebo-controlled diagnostic blocks $(30,31)$.

\section{Confounding Factors}

Of the studies reviewed, four articles evaluated diagnostic validity of facet joint blocks under multiple confounding conditions (35, 98-100). All four articles met criteria for inclusion by both AHRQ and QUADAS. Table 1 details these studies and includes methodological quality criteria.

False-positive rate of diagnostic facet joint blocks was evaluated in two groups of patients: with somatization disorder or without such a diagnosis (98). This study showed that somatization or other psychological factors including depression and generalized anxiety disorders failed to influence the diagnostic validity of lumbar facet joint blocks.

The diagnostic validity and therapeutic value of medial branch blocks with or without an adjuvant was also evaluated (35). This study noted no difference in the capacity to diagnose facet joint pain with local anesthetics administered alone or with mixtures of Sarapin and methylprednisolone.

Effect of sedation was evaluated in two prospective, randomized, double blind, placebo-controlled studies (99, 100). These studies showed that conscious sedation with midazolam or fentanyl is a confounding factor in the diagnosis of cervical or lumbar facet joint pain in patients with chronic neck or low back pain. However, these studies suggested that if strict criteria, including pain relief and ability to perform prior painful movements, is used as the standard for evaluating the effect of controlled local anesthetic blocks, the diagnostic validity of facet joint nerve blocks may be preserved. These confounding factors were less significant for lumbar facet joint pain than cervical facet joint pain. If $80 \%$ pain relief with ability to perform prior painful movements is used as the criterion standard in cervical spine, an intravenous preoperative sedative dose of an opioid, such as fentanyl, or an anxiolytic agent, such as midazolam, is no more likely to cause a small proportion of patients to report false-positive pain relief with active motion testing than sodium chloride placebo.

\section{Criterion Standard}

No tissue diagnosis (biopsy or autopsy) techniques are available to diagnose facet joint pain and confirm specificity and sensitivity of medial branch blocks. However, pain relief and stability of the diagnosis over a long period of time with long-term follow up are employed as the criterion standards and are accepted across multiple medical disciplines (74).

Several studies evaluating the effectiveness of various therapeutic modalities have shown the existence of facet joint pain. Furthermore, Manchikanti et al (97) established the diagnostic validity of lumbar medial branch blocks on longterm follow-up at two years after the initial diagnosis of lumbar facet joint pain in patients with chronic low back pain.

\section{Diagnosis of Facet Joint Pain}

Reliability of clinical history, physical examination, medical imaging, and other evaluations have been shown to be poor $(34)$. Revel et al $(67,68)$ found that a cluster of clinical signs were valuable in predicting the results of an initial screening facet joint block. They suggested that these clinical findings are unsuitable for diagnosis, but may be of value in selecting patients for diagnostic blocks of the lumbar facet joints. Two studies $(34,69)$ refuted these findings utilizing controlled, comparative local anesthetic blocks. Schwarzer et al $(49,56)$ evaluated the role of CT scanning and bone scintigraphy in chronic low back pain and showed poor correlation with facet joint injections. 
Schwarzer et al (51) and Manchikanti et al (34) evaluated various clinical findings to diagnose facet joint pain and concluded that they were unable to diagnose facet joint pain based on previous assumptions. Study characteristics are illustrated in Table 2.

Prevalence Multiple publications were examined sion criteria $(32-44,76-78), 12$ evaluat- ed lumbar facet joint pain, two evaluated thoracic facet joint pain, and five evaluated cervical facet joint pain. Two groups separately reported prevalence estimates for lumbar and cervical facet joint pain. Prevalence of thoracic facet joint pain is based on the reports of one group; this data has not been replicated. Details with study characteristics and methodological quality criteria are listed in Tables 3 to 5 .

Table 1. Description studies evaluating confounding factors

\begin{tabular}{|c|c|c|c|c|c|}
\hline Study & $\begin{array}{c}\text { \# of } \\
\text { Subjects }\end{array}$ & $\begin{array}{c}\text { Inclusion/Exclusion/ } \\
\text { Subject Characteristics }\end{array}$ & Interventions \& Variables & Outcome measures & Results \\
\hline $\begin{array}{l}\text { Manchikanti et al (35) } \\
\text { Prospective } \\
\text { AHRQ - } 3 / 5 \\
\text { QUADAS - } 10 / 14\end{array}$ & 180 & $\begin{array}{l}\text { Age: } 18-90 \text { yrs. } \\
\text { LBP }+/- \text { leg pain. } \\
\text { Failed conservative treatment. } \\
\text { No neurologic signs. } \\
\text { No prior blocks. } \\
\text { Single interventional pain } \\
\text { management practice. }\end{array}$ & $\begin{array}{l}\text { Double MBB: } \\
\text { Interval: } 2-4 \text { weeks, Volumes } \\
0.4-0.6 \text { ml, } 3 \text { groups: } 60 \text { each } \\
\text { I - LA ( } 1 \% \text { L \& } 0.25 \% \text { B) } \\
\text { II - LA + Sarapin } \\
\text { III - LA+Sarapin+ } \\
\text { Depomedrol } \\
\text { U/L blocks: } 33 \% \\
\text { B/L blocks: } 67 \% \\
\text { Sedation: mild with } \\
\text { midazolam }\end{array}$ & $\begin{array}{l}\geq 75 \% \text { pain relief } \\
\text { in symptomatic } \\
\text { area for duration of } \\
\text { anesthetic used and } \\
\text { bupivacaine (B) } \\
\text { effect longer than } \\
\text { lidocaine }(\mathrm{L}) \text { effect }\end{array}$ & $\begin{array}{l}\text { Prevalence: Average } 36 \% \\
\text { I - 38\% (95\% CI 26\%-50\%) } \\
\text { II - 32\% (95\% CI 20\%-44\%) } \\
\text { III - 38\% (95\% CI 26\%- } \\
50 \%) \\
\text { False-positive rate of single } \\
\text { blocks: Average } 25 \% \\
\text { I - 22\% (95\% CI 9\%-35\%) } \\
\text { II -27\% (95\% CI 13\%-41\%) } \\
\text { III -27\% (95\% CI } 13 \% 41 \%)\end{array}$ \\
\hline $\begin{array}{l}\text { Manchikanti et al (98) } \\
\text { Prospective } \\
\text { AHRQ - } 4 / 5 \\
\text { QUADAS - } 12 / 14\end{array}$ & 100 & $\begin{array}{l}>6 \text { months LBP }+/ \text { - lower } \\
\text { limb pain. } \\
\text { Age: } 18-90 \text { yrs. } \\
\text { Failed conservative treatment. } \\
\text { No neurologic signs } \\
\text { No definitive diagnosis on } \\
\text { radiologic test or } \\
\text { neuro-physiologic test. } \\
\text { MCMI-II to classify into } 2 \\
\text { groups: } \\
\text { Gp I: (50) non somatization } \\
\text { GpII: (50) somatization } \\
\text { Single interventional pain } \\
\text { management practice }\end{array}$ & $\begin{array}{l}\text { Double MBB: } \\
\text { Interval: } 2-4 \text { weeks } \\
\text { Volumes: } 0.4-0.6 \mathrm{ml} \\
1^{\text {st: Lidocaine } 1 \%} \\
2^{\text {nd: }} \text { Bupivacaine } 0.25 \% \\
\text { Sedation: mild with } \\
\text { midazolam }\end{array}$ & $\begin{array}{l}\text { Pain scores } \\
\text { Definite response: } \\
>80 \% \text { pain relief in } \\
\text { symptomatic area } \\
\text { for }>45 \text { minutes } \\
\text { with lidocaine } \& 2 \\
\text { hrs. or more after } \\
\text { Bupivacaine }\end{array}$ & $\begin{array}{l}\text { Prevalence } \\
\text { I - 44\% (95\% CI 30\%-58\%) } \\
\text { II - 38\% (95\% CI 24\%-52\%) } \\
\text { False- positive rate single } \\
\text { blocks: } \\
\text { I - } 29 \% \text { (95\% CI } 11 \%-46 \%) \\
\text { II - } 26 \%(95 \% \text { CI } 10 \%-42 \%)\end{array}$ \\
\hline $\begin{array}{l}\text { Manchikanti et al (99) } \\
\text { Randomized, double- } \\
\text { blind, placebo- } \\
\text { controlled } \\
\text { AHRQ - } 5 / 5 \\
\text { QUADAS - } 14 / 14\end{array}$ & 180 & $\begin{array}{l}\text { Chronic neck pain } \geq 1 \text {-year. } \\
\text { Facet joint pain diagnosed by } \\
\text { controlled, comparative local } \\
\text { anesthetic blocks. } \\
\text { Previously treated with } \\
\text { therapeutic medial branch } \\
\text { blocks. } \\
\text { Presented for repeat } \\
\text { treatments after a period of } \\
\text { pain relief. } \\
\text { Single interventional pain } \\
\text { management practice }\end{array}$ & $\begin{array}{l}\text { Subjects randomized to one } \\
\text { of the three groups. } \\
\text { Double blinded } \\
\text { intravenous administration } \\
\text { of one of the } 3 \text { solutions to } \\
\text { maximum dose as follows: } \\
\text { G1 - } 5 \mathrm{ml} \text { saline } \\
\text { GII - } 5 \mathrm{mg} \text { midazolam } \\
\text { GII - } 250 \mathrm{mcg} \text { fentanyl }\end{array}$ & $\begin{array}{l}\text { Outcomes at } \\
\text { baseline and after } \\
\text { administration of } 1 \\
\text { of the } 3 \text { solutions } \\
\text { Outcome measures: } \\
\text { numeric pain scale, } \\
\text { proportion of pain } \\
\text { relief, and ability } \\
\text { to perform prior } \\
\text { painful movements. }\end{array}$ & $\begin{array}{l}\text { IV sedation with midazolam } \\
\text { or fentanyl is a confounding } \\
\text { factor in cervical facet joint } \\
\text { pain diagnosis. If }>80 \% \\
\text { pain relief with ability } \\
\text { to perform prior painful } \\
\text { movements is used as the } \\
\text { standard for evaluating } \\
\text { the effect of controlled } \\
\text { local anesthetic blocks, } \\
\text { the diagnostic validity of } \\
\text { cervical facet joint nerve } \\
\text { blocks may be preserved. }\end{array}$ \\
\hline $\begin{array}{l}\text { Manchikanti et al } \\
(100) \\
\text { Randomized, double- } \\
\text { blind } \\
\text { AHRQ - } 5 / 5 \\
\text { QUADAS - } 14 / 14\end{array}$ & 180 & $\begin{array}{l}\text { Chronic, low back pain of at } \\
\text { least } 2 \text { years' duration. } \\
\text { Patients with facet joint pain } \\
\text { confirmed by controlled, } \\
\text { comparative local anesthetic } \\
\text { blocks of medial branches. } \\
\text { All subjects treated } \\
\text { previously with lumbar } \\
\text { facet joint nerve blocks and } \\
\text { were presenting for repeat } \\
\text { treatment after a significant } \\
\text { period of symptom relief. } \\
\text { Single interventional pain } \\
\text { management practice }\end{array}$ & $\begin{array}{l}\text { The design consisted of a } \\
\text { placebo group receiving } \\
\text { sodium chloride solution } \\
\text { and two experimental } \\
\text { groups receiving either } \\
\text { midazolam or fentanyl. } \\
\text { Subjects randomized to } \\
\text { one of the three groups to } \\
\text { receive intravenously in a } \\
\text { double blind fashion one of } \\
\text { the } 3 \text { solutions with } \\
\text { maximum doses: } \\
\text { G1 - 5ml saline } \\
\text { GII - 5mg midazolam } \\
\text { GII - } 250 \mathrm{mcg} \text { fentanyl }\end{array}$ & $\begin{array}{l}\text { Outcomes at } \\
\text { baseline and after } \\
\text { administration of } 1 \\
\text { of the } 3 \text { solutions } \\
\text { Outcome measures: } \\
\text { numeric pain scale, } \\
\text { proportion of pain } \\
\text { relief, and ability } \\
\text { to perform prior } \\
\text { painful movements. }\end{array}$ & $\begin{array}{l}\text { IV sedation with } \\
\text { midazolam or fentanyl is a } \\
\text { confounding factor in the } \\
\text { diagnosis of lumbar facet } \\
\text { joint pain. } \\
\text { If strict criteria including } \\
\text { pain relief and ability to } \\
\text { perform prior painful } \\
\text { movements are used as the } \\
\text { standard for evaluating } \\
\text { the effect of controlled } \\
\text { local anesthetic blocks, } \\
\text { the diagnostic validity of } \\
\text { lumbar facet joint nerve } \\
\text { blocks may be preserved. }\end{array}$ \\
\hline
\end{tabular}


Based on the results of these stud- chronic low back pain (32-40), 42\%-48\% alence of facet joint pain was reported in ies, facet joints have been implicated as a of the patients with thoracic pain $(40,41)$, individuals $<65$ years $(30 \%)$ compared to source of chronic spinal pain in $15 \%-45 \%$ and $54 \%-67 \%$ of the patients with chron- $\quad>65$ years age $(52 \%)(76)$, and in males of a heterogeneous group of patients with ic neck pain $(39,40,42-44)$. A lower prev- $\quad(38 \%)$ compared to females (43\%) (102).

Table 2. Characteristics of studies evaluating accuracy of non-interventional diagnostic techniques

\begin{tabular}{|c|c|c|c|c|c|}
\hline Study & $\begin{array}{c}\text { \# of } \\
\text { Subjects }\end{array}$ & $\begin{array}{l}\text { Inclusion/Exclusion } \\
\text { /subject Characteristics }\end{array}$ & Interventions \& Variables & Outcome measures & Results \\
\hline $\begin{array}{l}\text { Revel et al (67) } \\
\text { Prospective } \\
\text { AHRQ - } 4 / 5 \\
\text { QUADAS - } 12 / 14\end{array}$ & 51 & $\begin{array}{l}\text { Chronic low back pain. } \\
40 \text { patients included and } \\
1 \text { lexcluded due to unsuc- } \\
\text { cessful intraarticular in- } \\
\text { jection }\end{array}$ & $\begin{array}{l}\text { Single intraarticular facet } \\
\text { joint injection with ligno- } \\
\text { caine and extraarticular in- } \\
\text { jections with corticosteroid; } \\
2-6 \text { joints injected in one } \\
\text { session. } \\
\text { Ninety clinical variables col- } \\
\text { lected } 1 \text { week prior to in- } \\
\text { jection }\end{array}$ & $\begin{array}{l}\text { Positive response: }>75 \% \\
\text { pain relief } 30 \text { minutes } \\
\text { after last facet joint in- } \\
\text { jection } \\
\text { Correlation and identifi- } \\
\text { cation of predictors of a } \\
\text { good response and con- } \\
\text { firmation of diagnosis of } \\
\text { lumbar facet joint pain. }\end{array}$ & $\begin{array}{l}81.8 \% \text { sensitivity and } \\
77.8 \% \text { specificity for pres- } \\
\text { ence of } 4 \text { of the } 7 \text { variables } \\
\text { in same patient, } 7 \text { variables } \\
\text { were more frequent in the } \\
\text { responder group: older age, } \\
\text { absence of exacerbation by } \\
\text { coughing, relief when re- } \\
\text { cumbent, absence of exac- } \\
\text { erbation by forward flex- } \\
\text { ion and when raising from } \\
\text { flexion, absence of worsen- } \\
\text { ing by hyperextension, and } \\
\text { extension-rotation. }\end{array}$ \\
\hline $\begin{array}{l}\text { Revel et al (68) } \\
\text { Prospective, } \\
\text { randomized, double- } \\
\text { blind } \\
\text { AHRQ - } 4 / 5 \\
\text { QUADAS - } 12 / 14\end{array}$ & 80 & $\begin{array}{l}\text { LBP }>3 \text { months } \\
\text { VAS }>30 \text { mm on day of in- } \\
\text { jection } \\
\text { Seven clinical criteria: } \\
\text { age }>65 \text {; pain relief on } \\
\text { recumbency; no pain } \\
\text { increase by cough, } \\
\text { forward flexion, deflexion, } \\
\text { hyperextension, } \\
\text { extension-rotation }\end{array}$ & $\begin{array}{l}\text { Random select for ZJI with } \\
\text { Lidocaine/ or saline } \\
\text { injection } \\
\text { Excluded unsuccessful } \\
\text { injections Extraarticular } \\
\text { steroids in all }\end{array}$ & $\begin{array}{l}\text { Pain relief after Single } \\
\text { ZJI with Lidocaine (LI) } \\
\text { or normal saline (SI) in } \\
\text { group with \& without } \\
\text { Revel's clinical criteria } \\
\text { Positive response: } \\
<25 \% \text { of initial VAS } \\
\text { grade }\end{array}$ & $\begin{array}{l}\text { Revel's clinical criteria } \\
\text { identified } 92 \% \text { of respond- } \\
\text { ers and } 80 \% \text { of non-re- } \\
\text { sponders. Those respond- } \\
\text { ing had at least } 5 \text { clinical } \\
\text { criteria } \\
\text { p }<0.002\end{array}$ \\
\hline $\begin{array}{l}\text { Manchikanti et al } \\
(34) \\
\text { Prospective } \\
\text { AHRQ - } 3 / 5 \\
\text { QUADAS - } 11 / 14\end{array}$ & 200 & $\begin{array}{l}>6 \text { months } \\
\text { LBP }+/ \text { - leg pain } \\
\text { Failed conservative treat- } \\
\text { ment } \\
\text { No neurologic signs } \\
\text { No prior blocks } \\
\text { Age: } 18-90 \text { yrs } \\
\text { M/F: } 80 / 120 \\
\text { Post trauma: } 49 \% \\
\text { Post laminectomy: } 25 \% \\
\text { Single interventional pain } \\
\text { management practice }\end{array}$ & $\begin{array}{l}\text { Double medial branch block } \\
\text { Interval: } 2 \text { weeks } \\
\text { Volumes: } 0.4-0.6 \mathrm{ml} \\
1^{\text {st: }} \text { Lidocaine } 1 \% \\
2^{\text {nd: }} \text { Bupivacaine } 0.25 \% \\
\text { Sedation: mild } \\
\text { U/L block: } 34 \% \\
\mathrm{~B} / \mathrm{L} \text { block: } 66 \% \\
\text { Revel's criteria: age }>65 \text {; } \\
\text { Pain relief on recumbency; } \\
\text { no pain increase by cough, } \\
\text { forward flexion, deflexion, } \\
\text { hyperextension, external } \\
\text { rotation }\end{array}$ & $\begin{array}{l}\text { Percentage pain relief } \\
\text { and duration of pain re- } \\
\text { lief after first and second } \\
\text { blocks }>75 \% \text { pain relief } \\
\text { in symptomatic area for } \\
\text { duration of anesthetic } \\
\text { used and Bupivacaine } \\
\text { effect longer than Lido- } \\
\text { caine effect }\end{array}$ & $\begin{array}{l}\text { Lidocaine positive: } \\
127(64 \%) \\
\text { alse-positive: } 37 \% \\
(95 \% \text { CI } 28 \%-46 \%) \\
\text { Prevalence: } 42 \% \\
(95 \% \text { CI } 35 \%-49 \%) \\
\text { No correlation with Revel's } \\
\text { criteria } \\
\text { Significant negative corre- } \\
\text { lation with post laminec- } \\
\text { tomy, history of occupa- } \\
\text { tional injury, back pain on } \\
\text { SLR in double block posi- } \\
\text { tive group }\end{array}$ \\
\hline $\begin{array}{l}\text { Laslett et al (69) } \\
\text { Prospective, physical } \\
\text { therapist, blinded } \\
\text { AHRQ - } 4 / 5 \\
\text { QUADAS - } 12 / 14\end{array}$ & $\begin{array}{c}151 \\
\text { enrolled } \\
116 \\
\text { completed } \\
35 \\
\text { excluded }\end{array}$ & $\begin{array}{l}\text { Ch LBP +/-Lower limb pain } \\
\text { Measurements: VAS: cur- } \\
\text { rent, best, worst pain; } \\
\text { Roland Morris disability; } \\
\text { Zung Depression Index; } \\
\text { MSPQ; DRAM; } \\
\text { Revel's criteria } \\
\text { Private radiology practice }\end{array}$ & $\begin{array}{l}\text { Zygapophysial joint injec- } \\
\text { tion or medial branch block } \\
\text { with } 0.5 \mathrm{ml} \text { of } 2 \% \text { Lidocaine } \\
\text { Confirmatory MBB with } \\
0.75 \% \text { Bupivacaine in posi- } \\
\text { tive responders }\end{array}$ & $\begin{array}{l}\text { Positive response: pain } \\
\text { reduction or abolition } \\
\text { for } 1 \frac{1 / 2}{2} \text { hours after lido- } \\
\text { caine and for }>4 \text { hours } \\
\text { after bupivacaine in pos- } \\
\text { itive responders }\end{array}$ & $\begin{array}{l}\text { Revel's criteria have no } \\
\text { correlation with facet } \\
\text { joint pain }\end{array}$ \\
\hline $\begin{array}{l}\text { Schwarzer et al (51) } \\
\text { Prospective } \\
\text { AHRQ - } 3 / 5 \\
\text { QUADAS - } 11 / 14\end{array}$ & 176 & $\begin{array}{l}\text { All patients with chronic } \\
\text { low back pain without his- } \\
\text { tory of previous lumbar } \\
\text { surgery. } \\
\text { Site: radiology practice and } \\
\text { specialist spine practice }\end{array}$ & $\begin{array}{l}\text { Those patients responding } \\
\text { to the first series of blocks } \\
\text { were given confirmatory } \\
\text { blocks using bupivacaine }\end{array}$ & $\begin{array}{l}\text { Correlate the clini- } \\
\text { cal criteria as described } \\
\text { by Fairbank et al and } \\
\text { Helbig and Lee for zyg- } \\
\text { apophysial joint pain. }\end{array}$ & $\begin{array}{l}\text { None of the clinical fea- } \\
\text { tures tested were found } \\
\text { to be associated with re- } \\
\text { sponse to the confirma- } \\
\text { tory block. }\end{array}$ \\
\hline $\begin{array}{l}\text { Schwarzer et al (56) } \\
\text { Prospective, } \\
\text { placebo-controlled } \\
\text { cross-sectional, } \\
\text { analytic study } \\
\text { AHRQ - } 4 / 5 \\
\text { QUADAS - } 12 / 14\end{array}$ & 63 & $\begin{array}{l}63 \text { patients with low back } \\
\text { pain lasting for longer than } \\
3 \text { months. } \\
6 \text { were excluded from evalu- } \\
\text { ation because of unsuccess- } \\
\text { ful injection into the joints } \\
\text { as planned. }\end{array}$ & $\begin{array}{l}\text { All patients underwent com- } \\
\text { puted tomography and pla- } \\
\text { cebo-controlled blocks of } \\
\text { the zygapophysial joints at } \\
\text { L3/4, L4/5, and L5/S1. } \\
\text { Three independent, masked } \\
\text { radiologists scored the zyg- } \\
\text { apophysial joints of all im- } \\
\text { ages. }\end{array}$ & $\begin{array}{l}\text { Interobserver agreement } \\
\text { with intraclass correla- } \\
\text { tion coefficient using to- } \\
\text { tal joint scores for all } 3 \\
\text { assessors }\end{array}$ & $\begin{array}{l}\text { Computed tomography } \\
\text { has no place in the diagno- } \\
\text { sis of lumbar zygapophy- } \\
\text { sial joint pain }\end{array}$ \\
\hline
\end{tabular}


Table 3. Study characteristics evaluating prevalence of cervical facet joint pain

\begin{tabular}{|c|c|c|c|c|c|}
\hline Study & \# of Subjects & $\begin{array}{l}\text { Inclusion/Exclusion / } \\
\text { subject Characteristics }\end{array}$ & Interventions \& Variables & Outcome measures & Results \\
\hline Manchikanti et al (39) & 120 & $\begin{array}{l}>6 \text { months } \\
\text { NP+LBP }\end{array}$ & $\begin{array}{l}\text { Double MBB: } \\
\text { Interval: } 3-4 \text { weeks }\end{array}$ & $\begin{array}{l}\text { Pain relief, and } \\
\text { ability to perform }\end{array}$ & $\begin{array}{l}\text { Prevalence: } 67 \% \\
(95 \% \text { CI } 58 \%-75 \%)\end{array}$ \\
\hline \multirow[t]{3}{*}{ Prospective } & & Age: $18-90 \mathrm{yrs}$ & Volumes: $0.5 \mathrm{ml}$ & previously painful & \\
\hline & & Failed conservative treatment & $1^{\text {st: }}$ Lidocaine $1 \%$ & movements & \\
\hline & & No definite diagnosis & $2^{\text {nd: }}$ Bupivacaine $0.25 \%$ & & \\
\hline \multirow[t]{2}{*}{ AHRQ - 3/5 } & & No neurologic signs & & & \\
\hline & & No prior blocks & & & \\
\hline QUADAS - $10 / 14$ & & $\begin{array}{l}\text { Single interventional pain } \\
\text { management practice }\end{array}$ & & & \\
\hline Manchikanti et al (40) & $\begin{array}{c}255 \text { of } 500 \\
\text { patients }\end{array}$ & $>6$ months nonradicular pain & $\begin{array}{l}\text { Double MBB: } \\
\text { Interval: } 3-4 \text { weeks }\end{array}$ & $\begin{array}{l}\text { Pain relief and } \\
\text { ability to perform }\end{array}$ & $\begin{array}{l}\text { Prevalence } \\
\text { Cervical: } 55 \%\end{array}$ \\
\hline Prospective & & $\begin{array}{l}\text { Age: } 18-90 \text { yrs } \\
\text { Failed conservative treatment }\end{array}$ & $\begin{array}{l}\text { Mild IV sedation with Mid- } \\
\text { azolam }\end{array}$ & $\begin{array}{l}\text { previously painful } \\
\text { movements }\end{array}$ & (95\% CI 49\%-61\%) \\
\hline \multirow[b]{2}{*}{ AHRQ - 3/5 } & & No neurologic findings & Volumes: $0.5 \mathrm{ml}$ & & \\
\hline & & & $1^{\text {st: }}:$ Lidocaine $1 \%$ & & \\
\hline \multirow[b]{2}{*}{ QUADAS - $11 / 14$} & & Single interventional pain & $2^{\text {nd }}:$ Bupivacaine $0.25 \%$ & & \\
\hline & & management practice & $\begin{array}{l}\text { Sedation: mild with mid- } \\
\text { azolam }\end{array}$ & & \\
\hline Barnsley et al (42) & 50 & $\begin{array}{l}\text { Age }>18 \text { years } \\
\text { NP }>3 \text { months }\end{array}$ & $\begin{array}{l}\text { Double MBB } \\
\text { Interval: } 2 \text { weeks }\end{array}$ & $\begin{array}{l}\text { Degree / duration of } \\
\text { pain relief }\end{array}$ & $\begin{array}{l}\text { Prevalence: } 54 \% \\
(95 \% \text { CI } 40 \%-68 \%)\end{array}$ \\
\hline \multirow{3}{*}{$\begin{array}{l}\text { Prospective, double- } \\
\text { blind }\end{array}$} & 7 withdrew & Following MVA & Volumes: $0.5 \mathrm{ml} \mathrm{LA}$ & & \\
\hline & reasons given & Failed conservative treatment & VAS, McGill, pain diagrams & & \\
\hline & 5 did not & Tertiary referral unit & Psychologic symptom check & & \\
\hline $\begin{array}{l}\text { AHRQ - } 4 / 5 \\
\text { QUADAS - } 13 / 14\end{array}$ & $\begin{array}{l}\text { complete } \\
\text { blocks }\end{array}$ & & list SCL-90R & & \\
\hline \multirow{9}{*}{$\begin{array}{l}\text { Lord et al (43) } \\
\text { Randomized, controlled, } \\
\text { double-blind, placebo- } \\
\text { controlled } \\
\text { Independent observer to } \\
\text { corroborate needle tip } \\
\text { position } \\
\text { Blinding of subject, \& } \\
\text { operator to agent se- } \\
\text { quence } \\
\text { AHRQ - } 4 / 5 \\
\text { QUADAS - } 13 / 14 \\
\end{array}$} & 68 & $\begin{array}{l}\text { Chronic neck pain and head- } \\
\text { ache after whiplash }\end{array}$ & $\begin{array}{l}\text { TON block to exclude } \mathrm{C} 2-3 \\
\text { facet pain }\end{array}$ & $\begin{array}{l}\text { Pain relief extent and } \\
\text { duration on tele- }\end{array}$ & $\begin{array}{l}50 \% \text { prevalence } \\
\text { of C2-3 facet pain }\end{array}$ \\
\hline & 11 withdrew & Tertiary referral unit & $\begin{array}{l}3 \text { injections distal to } \mathrm{C} 2-3 \\
\text { facet joint }\end{array}$ & phone contact & (95\% CI 29\%-71\%) \\
\hline & 5 did not & & Double blind, random order & Positive response: & Overall prevalence \\
\hline & complete & & $\begin{array}{l}\text { Volumes: } 0.5 \mathrm{ml} \\
1^{\text {st }} \text { injiction. } 2 \% \text { Lidocaine or }\end{array}$ & $\begin{array}{l}\text { Complete relief }+ \\
\text { reproducible relief }\end{array}$ & (including C2-3 facet \\
\hline & & & $0.5 \%$ Bupivacaine & with local anesthetics & $(95 \%$ CI $46 \%-73 \%)$ \\
\hline & & & $2^{\text {nd }}$ and $3^{\text {rd }}$ injections: saline & but not placebo & \\
\hline & & & $\begin{array}{l}\text { or anesthetic not used in first } \\
\text { injection }\end{array}$ & & $\begin{array}{l}\text { Most common facet } \\
\text { levels: C2-3 and C5-6 }\end{array}$ \\
\hline & & & VAS, McGill, SCL-90R & & \\
\hline & & & & & \\
\hline \multirow[t]{2}{*}{ Manchikanti et al (44) } & & $>6$ months & Double MBB: C2-3 to C6-7 & Pain scores and & Prevalence: $60 \%$ \\
\hline & 106 & $\mathrm{NP}+/$-Headaches & levels & ability to perform & (95\% CI 50\%-70\%) \\
\hline \multirow{3}{*}{ Prospective } & & Age: $18-90$ yrs & Interval: $2-4$ weeks & previously painful & \\
\hline & & Failed conservative treat & Volumes: $0.5 \mathrm{ml}$ & movements & \\
\hline & & No neurologic signs & $1^{\text {st: Lidocaine } 1 \%}$ & & \\
\hline AHRQ - 3/5 & & No prior blocks & $2^{\text {nd. }}$ Bupivacaine $0.25 \%$ & & \\
\hline QUADAS - $10 / 14$ & & $\begin{array}{l}\text { Single interventional pain } \\
\text { management practice }\end{array}$ & $\begin{array}{l}\text { Sedation: mild with mid- } \\
\text { azolam }\end{array}$ & & \\
\hline
\end{tabular}

Table 4. Study characteristics evaluating prevalence of thoracic facet joint pain

\begin{tabular}{|c|c|c|c|c|c|}
\hline Study & \# of Subjects & $\begin{array}{l}\text { Inclusion/Exclusion } \\
\text { /subject Characteristics }\end{array}$ & $\begin{array}{l}\text { Interventions \& } \\
\text { Variables }\end{array}$ & Outcome measures & Results \\
\hline $\begin{array}{l}\text { Manchikanti et al (40) } \\
\text { Prospective } \\
\text { AHRQ - } 3 / 5 \\
\text { QUADAS - } 11 / 14\end{array}$ & $\begin{array}{l}72 \text { of } 500 \\
\text { patients }\end{array}$ & $\begin{array}{l}>6 \text { months nonradicular chronic NP, } \\
\text { TP, LBP or combination } \\
\text { Age: } 18-90 \text { yrs } \\
\text { Failed conservative treatment } \\
\text { No neurologic findings } \\
\text { Single interventional pain } \\
\text { management practice }\end{array}$ & $\begin{array}{l}\text { Double MBB: } \\
\text { Interval: } 3-4 \text { weeks } \\
\text { Mild IV sedation } \\
\text { with Midazolam } \\
\text { Volumes: } 0.5 \mathrm{ml} \\
1^{\text {st: }} \text { Lidocaine } 1 \% \\
2^{\text {nd: }} \text { : Bupivacaine } 0.25 \%\end{array}$ & $\begin{array}{l}\text { Pain relief and } \\
\text { ability to perform } \\
\text { painful movements }\end{array}$ & $\begin{array}{l}\text { Prevalence } \\
\text { Thoracic: } 42 \% \\
(95 \% \text { CI } 30 \%-53 \%)\end{array}$ \\
\hline $\begin{array}{l}\text { Manchikanti et al (41) } \\
\text { Prospective } \\
\text { AHRQ - } 3 / 5 \\
\text { QUADAS - } 10 / 14\end{array}$ & 46 & $\begin{array}{l}>6 \text { months } \\
\text { Non radicular TP } \\
\text { Age: } 18-90 \text { yrs } \\
\text { Failed conservative treat } \\
\text { Single interventional pain } \\
\text { management practice }\end{array}$ & $\begin{array}{l}\text { Double MBB: } \\
\text { Interval: } 3-4 \text { weeks } \\
\text { Mild IV sedation with } \\
\text { Midazolam } \\
\text { Volumes: } 0.5 \mathrm{ml} \\
1^{\text {st: }} \text { Lidocaine } 1 \% \\
2^{\text {nd: }} \text { Bupivacaine } 0.25 \%\end{array}$ & $\begin{array}{l}\text { Pain relief and } \\
\text { ability to perform } \\
\text { previously painful } \\
\text { movements }\end{array}$ & $\begin{array}{l}\text { Prevalence: } 48 \% \\
(95 \% \text { CI } 34 \%-62 \%)\end{array}$ \\
\hline
\end{tabular}


A history of trauma/occupational injury and prior lumbar spine surgery negatively correlated with prevalence of facet joint pain $(33,34,77,102)$ while smoking
(102), somatization, anxiety, or depression (98) did not increase the prevalence of facet joint pain.

\section{Complications}

There was one vasovagal episode and short duration procedure-related discomfort reported by one study (105). No ma-

Table 5. Study characteristics evaluating prevalence of lumbar facet joint pain

\begin{tabular}{|c|c|c|c|c|c|}
\hline Study & $\begin{array}{c}\text { \# of } \\
\text { Subjects }\end{array}$ & $\begin{array}{l}\text { Inclusion/Exclusion } \\
\text { /subject Characteristics }\end{array}$ & Interventions \& Variables & Outcome measures & Results \\
\hline $\begin{array}{l}\text { Schwarzer et al (32) } \\
\text { Prospective } \\
\text { AHRQ - 4/5 } \\
\text { QUADAS - 12/14 }\end{array}$ & $\begin{array}{c}176 \\
71 \\
\text { completed }\end{array}$ & $\begin{array}{l}\text { LBP pain severe enough to refer / } \\
\text { no prior surgery/ no neuro sign } \\
\text { Site: radiology practice+ } \\
\text { Specialist spine private practice }\end{array}$ & $\begin{array}{l}\text { Double MBB } \\
2 \% \text { lidocaine } 0.5 \mathrm{~mL} \\
0.5 \% \text { bupivacaine } 0.5 \mathrm{~mL}\end{array}$ & $\begin{array}{l}\text { VAS Pain scores, and } \\
\text { ability to perform } \\
\text { painful movements. }\end{array}$ & $\begin{array}{l}\text { Prevalence: } 15 \% \\
(95 \% \text { CI } 10 \%-20 \%)\end{array}$ \\
\hline $\begin{array}{l}\text { Manchikanti et al } \\
(33) \\
\text { Prospective } \\
\text { AHRQ - 3/5 } \\
\text { QUADAS - } 8 / 14\end{array}$ & 120 & $\begin{array}{l}>6 \text { months LBP }+/- \text { leg pain } \\
\text { No neurologic signs } \\
\text { No prior blocks } \\
\text { Single interventional pain } \\
\text { management practice }\end{array}$ & $\begin{array}{l}\text { Double MBB } \\
\text { Interval: } 2 \text { weeks } \\
\text { Volumes: } 0.4-0.6 \mathrm{ml} \\
1^{\text {st: Lidocaine } 1 \%} \\
2^{\text {nd: }} \text { Bupivacaine } 0.25 \%\end{array}$ & $\begin{array}{l}\text { Percentage pain relief } \\
\text { and duration of pain } \\
\text { relief after first and } \\
\text { second blocks, and } \\
\text { ability to perform } \\
\text { painful movements. }\end{array}$ & $\begin{array}{l}\text { Prevalence: } 45 \% \\
(95 \% \text { CI } 36 \%-54 \%)\end{array}$ \\
\hline $\begin{array}{l}\text { Manchikanti et al } \\
(34) \\
\text { Prospective } \\
\text { AHRQ - 3/5 } \\
\text { QUADAS - 11/14 }\end{array}$ & 200 & $\begin{array}{l}>6 \text { months LBP }+/ \text { - leg pain } \\
\text { Failed conservative treat } \\
\text { No neurologic signs } \\
\text { No prior blocks } \\
\text { Single interventional pain } \\
\text { management practice }\end{array}$ & $\begin{array}{l}\text { Double MBB } \\
\text { Interval: } 2 \text { weeks } \\
\text { Volumes: } 0.4-0.6 \mathrm{ml} \\
1^{\text {st: Lidocaine } 1 \%} \\
2^{\text {nd: }} \text { Bupivacaine } 0.25 \%\end{array}$ & $\begin{array}{l}\text { Percentage pain relief } \\
\text { and duration of pain } \\
\text { relief, and ability } \\
\text { to perform painful } \\
\text { movements. }\end{array}$ & $\begin{array}{l}\text { Prevalence: } 42 \% \\
(95 \% \text { CI } 35 \%-49 \%)\end{array}$ \\
\hline $\begin{array}{l}\text { Manchikanti et al } \\
(35) \\
\text { Prospective, patient } \\
\text { self selected group } \\
\text { AHRQ - } 3 / 5 \\
\text { QUADAS - } 10 / 14\end{array}$ & 180 & $\begin{array}{l}\text { Age: } 18-90 \text { yrs } \\
\text { LBP }+/- \text { leg pain } \\
\text { Failed conservative treatment } \\
\text { No neurologic signs } \\
\text { No prior blocks } \\
\text { Single interventional pain } \\
\text { management practice }\end{array}$ & $\begin{array}{l}\text { Double MBB: } \\
\text { Interval: } 2-4 \text { weeks } \\
\text { Volumes } 0.4-0.6 \mathrm{ml} \\
3 \text { groups: } 60 \text { /group } \\
\text { Gr I: LA ( } 1 \% \text { Lidocaine \& } \\
\text { 0.25\% Bupivacaine) } \\
\text { GrII: LA + sarapin } \\
\text { Gr III: LA+ } \\
\text { sarapin+depomedrol }\end{array}$ & $\begin{array}{l}\text { Percentage pain relief } \\
\text { and duration of pain } \\
\text { relief, and ability } \\
\text { to perform painful } \\
\text { movements. }\end{array}$ & $\begin{array}{l}\text { Prevalence: } 36 \% \\
\text { Gp I: } 38 \% \\
\text { (95\% CI } 26 \%-50 \%) \\
\text { Gp II: } 32 \% \\
(95 \% \text { CI } 20 \%-44 \%) \\
\text { Gp III: } 38 \% \\
(95 \% \text { CI } 26 \%-50 \%)\end{array}$ \\
\hline $\begin{array}{l}\text { Schwarzer et al (36) } \\
\text { Prospective, single- } \\
\text { blind } \\
\text { Subjects blind to } \\
\text { agent and sequence } \\
\text { of joint injections } \\
\text { AHRQ - 4/5 } \\
\text { QUADAS - } 12 / 14\end{array}$ & $\begin{array}{l}63 \text { enrolled } \\
\\
57 \\
\text { completed }\end{array}$ & $\begin{array}{l}18-80 \text { years with chronic } \\
\text { mechanical LBP; no known cause } \\
\text { on imaging; } \\
\text { failed conservative treatment } \\
\text { Subjects referred by rheumatology } \\
\text { at tertiary referral teaching hospital }\end{array}$ & $\begin{array}{l}1^{\text {st }} \text { inj: } 0.5 \mathrm{ml} \text { saline inj } \\
\text { in paraspinal muscle } \\
\text { (placebo) } \\
\text { Subsequent injections: } \\
\text { intraarticular facet joint } \\
\text { with } 0.3 \text { contrast }+0.5 \% \\
\text { Bupivacaine } \\
\text { Volume }<1.5 \mathrm{ml}\end{array}$ & $\begin{array}{l}\text { Pain scores, } \\
\text { intraobserver agreement } \\
\text { on range of motion tests }\end{array}$ & $\begin{array}{l}\text { Prevalence } 40 \% \\
\text { L4-5 and L5-S1 facet } \\
\text { joints most common }\end{array}$ \\
\hline $\begin{array}{l}\text { Manchikanti et al } \\
(37) \\
\text { Prospective } \\
\text { AHRQ - } 4 / 5 \\
\text { QUADAS - } 10 / 14\end{array}$ & 120 & $\begin{array}{l}\text { 18-90 years with chronic low back } \\
\text { pain and no neurological deficits. } \\
\text { Single interventional pain } \\
\text { management practice }\end{array}$ & $\begin{array}{l}\text { Double blocks with } 1 \% \\
\text { Xylocaine and } 0.25 \% \\
\text { bupivacaine }\end{array}$ & $\begin{array}{l}\text { Percent and duration of } \\
\text { pain relief with ability } \\
\text { to perform painful } \\
\text { movements }\end{array}$ & $\begin{array}{l}\text { Prevalence: } 40 \% \\
(95 \% \text { CI } 31 \%-49 \%)\end{array}$ \\
\hline $\begin{array}{l}\text { Manchikanti et al } \\
(38) \\
\text { Prospective } \\
\text { AHRQ - } 4 / 5 \\
\text { QUADAS - } 12 / 14\end{array}$ & 300 & $\begin{array}{l}\text { Chronic low back pain } \\
\text { With involvement of: } \\
\text { single region: } n=150 \\
\text { multiple regions: } n=150 \\
\text { Single interventional pain } \\
\text { management practice }\end{array}$ & $\begin{array}{l}\text { Double medial branch } \\
\text { blocks with } 1 \% \text { lidocaine } \\
\text { and } 0.25 \% \text { bupivacaine. }\end{array}$ & $\begin{array}{l}\text { Pain relief and ability } \\
\text { to perform previously } \\
\text { painful movements. }\end{array}$ & $\begin{array}{l}\text { Prevalence: } \\
\text { I : } 21 \% \\
(95 \% \text { CI } 14 \%-27 \%) \\
\text { II : } 41 \% \\
(95 \% \text { CI } 33 \%-49 \%)\end{array}$ \\
\hline $\begin{array}{l}\text { Manchikanti et al } \\
(39) \\
\text { Prospective } \\
\text { AHRQ- } 3 / 5 \\
\text { QUADAS - } 10 / 14\end{array}$ & 120 & $\begin{array}{l}>6 \text { months } \\
\text { Neck pain }+ \text { LBP } \\
\text { Age: } 18-90 \text { yrs } \\
\text { Failed conservative treatment } \\
\text { No definite diagnosis } \\
\text { Single interventional pain } \\
\text { management practice }\end{array}$ & $\begin{array}{l}\text { Double medial branch } \\
\text { block } \\
1^{\text {st: Lidocaine } 1 \%} \\
2^{\text {nd: }} \text { Bupivacaine } 0.25 \%\end{array}$ & $\begin{array}{l}\text { Pain relief and ability } \\
\text { to perform previously } \\
\text { painful movements }\end{array}$ & $\begin{array}{l}\text { Prevalence: } 40 \% \\
(95 \% \text { CI } 31 \%, 49 \%)\end{array}$ \\
\hline $\begin{array}{l}\text { Manchikanti et al } \\
(40) \\
\text { Prospective } \\
\text { AHRQ - } 3 / 5 \\
\text { QUADAS - } 11 / 14\end{array}$ & $\begin{array}{c}397 \text { of } 500 \\
\text { patients }\end{array}$ & $\begin{array}{l}>6 \text { months nonradicular } \\
\text { LBP } \\
\text { Age: } 18-90 \text { yrs } \\
\text { Failed conservative treatment } \\
\text { No neuro findings } \\
\text { Single interventional pain } \\
\text { management practice }\end{array}$ & $\begin{array}{l}\text { Double medial branch } \\
\text { block } \\
1^{\text {st }} \text { Lidocaine } 1 \% \\
2^{\text {nd }} \text { : Bupivacaine } 0.25 \%\end{array}$ & $\begin{array}{l}\text { Pain relief and ability } \\
\text { to perform painful } \\
\text { movements }\end{array}$ & $\begin{array}{l}\text { Prevalence: } 31 \% \text { (95\% } \\
\text { CI } 27 \%-36 \%)\end{array}$ \\
\hline
\end{tabular}


jor complications were reported in any of the studies.

\section{False-Positive Rates}

After careful reading, 14 relevant studies evaluating false-positive rates were included for evidence synthesis. All of the studies reported false-positive rates either independently or in conjunction with other parameters. The details are shown in Table 6 (33-35, 37-41, 44, 75-79). These studies implicated single blocks as a source of false-positive results in $27 \%-63 \%$ of patients in the cervical spine $(39,40,44,75), 55 \%-58 \%$ of the patients in the thoracic spine $(40,41)$, and $17 \%-47 \%$ in the lumbar spine $(33-35,37-$ $40,76-79)$.

\section{Strength of Evidence}

Based on review of all available studies meeting our inclusion criteria, there is strong evidence that controlled diagnostic facet joint blocks establish diagnosis of facet joint pain in chronic spinal pain of cervical and lumbar origin, and moderate evidence for thoracic facet joint pain.

\section{DISCUSSION}

This systematic review provides moderate to strong evidence that controlled diagnostic facet joint blocks are safe, valid, and reliable, while uncontrolled facet joint injections are associated with a significant and variable false-positive rate. When performed under fluoroscopic visualization, utilizing IASP criteria (85), facet joint blocks are accurate and clinically useful in the diagnosis and therapeutic management of chronic spinal pain. The diagnostic accuracy of facet or zygapophysial joint blocks is strong for cervical and lumbar facet joints, and moderate for thoracic facet joints. In contrast to other available diagnostic techniques, needle diagnostic interventional techniques can diagnose facet joint pain with a high level of certainty.

Based on the present systematic review, we conclude facet joint pain is seen in $15 \%-45 \%$ of patients with chronic low back pain (32-40), $42 \%-48 \%$ of the patients with mid back or upper back pain $(40,41)$, and $54 \%-67 \%$ of patients with chronic neck pain $(39,40,42-44)$. Falsepositive rates with single blocks are $17 \%$ $47 \%$ in the lumbar spine $(33-35,37-40$, $76-79), 27 \%-63 \%$ in the cervical spine $(39,40,44,75)$, and $55 \%-58 \%$ in the thoracic spine $(40,41)$ (Table 6$)$.
The strength of this review is based on its compliance with stringent AHRQ (92) and QUADAS (93) criteria for evaluation of diagnostic tests. According to AHRQ criteria, each study was evaluated in five key domains and essential elements: study population, adequate description of the test, appropriate reference standard, blinded comparison of test and reference, and avoidance of verification bias. All studies met at least three criteria for inclusion as recommended by AHRQ. Fulfilling all five AHRQ criteria is difficult, partly because some of the criteria are not relevant to interventional diagnostic techniques. QUADAS, recently developed by Whiting et al (93), is an evidence-based tool for quality assessment of studies of diagnostic accuracy. The tool consists of a set of 14 items, phrased as questions, each of which should be scored as Yes, No, or Unclear. The items cover bias, variability, and to a certain extent, the quality of reporting. The majority of items included in QUADAS relate to bias (items 3-7, 10 12 , and 14), two items relate to variability (items 1 and 2), and three to reporting (items 8,9, and 13). The tool is simple and quick to complete and does not incorporate a quality score. We considered QUADAS as an appropriate tool and therefore used it for evaluating the diagnostic accuracy of studies in this systematic review. A methodological score was determined for each study based on QUADAS.

Hildebrandt (73), Saal (74), North et al (71), Hogan and Abram (72), Bogduk (27), Boswell et al (28), and Manchikanti et al (2) described challenges related to diagnostic blocks. North et al (71) examined the specificity and sensitivity of a battery of local anesthetic blocks in a series of 33 patients with a complaint of sciatica, attributable to spinal disease. In a blinded randomized sequence, subjects received three different types of nerve blocks and subcutaneous injection of $0.5 \%$ bupivacaine. The nerve blocks were significantly more effective than control injection of an identical volume of $3 \mathrm{~mL}$ of $0.5 \%$ bupivacaine subcutaneously in the lumbar area. A majority of the patients reported temporary relief not only with lumbosacral nerve root blocks, and medial branch posterior primary ramus blocks, but also with sciatic nerve blocks (distal or collateral to the pathology), lending support to the study hypothesis that specificity of diagnostic nerve blocks is low and false-positive results are com- mon. Strongest association was observed between relief by sciatic nerve block and relief by medial branch posterior primary ramus or facet block; no association was noted between the results of blocks and clinical findings including imaging studies. These authors concluded that uncontrolled local anesthetic blocks had a limited role in the diagnostic evaluation of sciatica and referred pain syndromes in general and that negative blocks as a pattern of response may have some predictive value, but isolated, positive blocks are nonspecific. However, they conceded that this lack of specificity might be advantageous in therapeutic applications. Thus, North et al (71) affirmed the necessity of controlled diagnostic blocks, while discrediting uncontrolled diagnostic blocks.

A criticism with regards to diagnostic facet joint blocks is related to the criterion standard. It is recognized that the accuracy of a diagnostic test is best determined by comparing it to an appropriate reference standard such as biopsy, surgery, autopsy, or long-term follow-up $(106,107)$. A gold or criterion standard allows accurate comparison of the capacity of a given diagnostic test to yield positive results when the clinical condition is present, and negative results when the clinical condition is not present. Thus, a gold or criterion standard facilitates accurate determination of the specificity and sensitivity of a test. Tissue confirmation of presence or absence of a disease at surgery, biopsy, or autopsy has served as the accepted criterion standard across multiple medical disciplines; it is, however, not applicable to diagnostic facet joint nerve blocks. There is no histopathologic marker and hence no justification for surgical intervention or biopsy to confirm or exclude facet joint pain. Consequently, as described by many authors, stability of the diagnosis over a long period of time with long-term follow-up is used as a criterion standard. In addition, for most interventional techniques, abolition or reproduction of the patient's pain symptoms must be considered as a criterion standard (74).

Saal (74) compared precision diagnostic injections to physical examination tests rather than most laboratory tests used in clinical medicine. Needle diagnostic injection techniques have several benefits as compared to traditional diagnostic methods: ability to access facet joints and nerves to the joints, normally inaccessible to palpation; ability to target facet 
Table 6. Data of prevalence with controlled diagnostic blocks and false-positive rates of single facet joint blocks in cervical, thoracic, and lumbar regions

\begin{tabular}{|c|c|c|c|c|c|}
\hline Study & Region & \# of Subjects & Type & Prevalence & False-Positive Rate \\
\hline Barnsley et al (75) 1993 & $\mathrm{C}$ & 55 & RCT & NA & $27 \%$ (95\% CI 15\%-38\%) \\
\hline Barnsley et al (42) 1995 & $\mathrm{C}$ & 50 & $\mathrm{P}, \mathrm{DB}$ & $54 \%$ (95\% CI 40\%-68\%) & NA \\
\hline Lord et al (43) 1996 & $\mathrm{C}$ & 68 & RCT, DB, PC & $60 \%$ (95\% CI 46\%-73\%) & NA \\
\hline Manchikanti et al (44) 2002 & $\mathrm{C}$ & 106 & $\mathrm{P}$ & $60 \%$ (95\% CI 50\%-70\%) & $40 \%(95 \%$ CI $25 \%-56 \%)$ \\
\hline Manchikanti et al (39) 2002 & $\mathrm{C}$ & 120 & $\mathrm{P}$ & $67 \%$ (95\% CI 58\%-75\%) & $63 \%$ (95\% CI 48\%-78\%) \\
\hline Manchikanti et al (40) 2004 & $\mathrm{C}$ & 255 of 500 patients & $\mathrm{P}$ & $55 \%$ (95\% CI 49\%-61\%) & $63 \%$ (95\% CI 54\%-72\%) \\
\hline Manchikanti et al (40) 2004 & $\mathrm{~T}$ & 72 of 500 patients & $\mathrm{P}$ & $42 \%$ (95\% CI 30\%-53\%) & $55 \%(95 \%$ CI 39\%-78\%) \\
\hline Manchikanti et al (41) 2002 & $\mathrm{~T}$ & 46 & $\mathrm{P}$ & $48 \%$ (95\% CI $34 \%-62 \%)$ & $58 \%$ (95\% CI 38\%-78\%) \\
\hline Schwarzer et al (32) 1994 & $\mathrm{~L}$ & 176 & $\mathrm{P}$ & $15 \%$ (95\% CI 10\%-20\%) & NA \\
\hline Schwarzer et al (79) 1994 & $\mathrm{~L}$ & 176 & $\begin{array}{l}\text { Subjects from } \\
\text { previous study }\end{array}$ & $15 \%$ & $38 \%(95 \%$ CI $30 \%-46 \%)$ \\
\hline Schwarzer et al (36) 1995 & $\mathrm{~L}$ & 63 & $\mathrm{P}, \mathrm{SB}$ & $40 \%$ (95\% CI 27\%-53\%) & NA \\
\hline Manchikanti et al (33) 1999 & $\mathrm{~L}$ & 120 & $\mathrm{P}$ & $45 \%$ (95\% CI 36\%-54\%) & $41 \%$ (95\% CI 29\%-53\%) \\
\hline Manchikanti et al (34) 2000 & $\mathrm{~L}$ & 200 & $\mathrm{P}$ & $42 \%$ (95\% CI 35\%-49\%) & $37 \%$ (95\% CI $28 \%-46 \%)$ \\
\hline Manchikanti (35) 2000 & $\mathrm{~L}$ & 180 & $\begin{array}{c}\mathrm{P} \\
\text { Psuedo } \\
\text { randomized }\end{array}$ & $\begin{array}{c}\text { Average } 36 \% \\
\text { I: } 38 \% \text { (CI } 26 \%-50 \% \text { ) } \\
\text { II: } 32 \% \text { (CI } 20 \%-44 \%) \\
\text { III: } 38 \% \text { (CI } 26 \%-50 \% \text { ) }\end{array}$ & $\begin{array}{c}\text { Average } 25 \% \\
\text { I: } 22 \%(\text { CI } 9 \%-35 \%) \\
\text { II: } 27 \%(\text { CI } 13 \%-41 \%) \\
\text { III: } 27 \%(\text { CI } 13 \%-41 \%)\end{array}$ \\
\hline Manchikanti et al (37) 2001 & $\mathrm{~L}$ & 120 & $\mathrm{P}$ & $40 \%(95 \%$ CI $31 \%, 49 \%)$ & $47 \%(95 \%$ CI $35 \%, 59 \%)$ \\
\hline Manchikanti et al (76) 2001 & $\mathrm{~L}$ & $\begin{array}{l}\text { Gp I }(\leq 65 \text { years })=50 \\
\text { Gp II }(\geq 65 \text { years })=50\end{array}$ & $P$ & $\begin{array}{l}\text { I: } 30 \% \text { CI } 17 \%-43 \%) \\
\text { II: } 52 \% \text { CI } 38 \%-66 \%)\end{array}$ & $\begin{array}{l}\text { I: } 26 \% \text { CI } 11 \%-40 \%) \\
\text { II: } 33 \% \text { CI } 14 \%-35 \%)\end{array}$ \\
\hline Manchikanti et al (77) 2001 & $\mathrm{~L}$ & $\begin{array}{c}\text { Gp I (no prior } \\
\text { surgery) }=50 \\
\text { Gp II (prior surgery) }=50\end{array}$ & $P$ & $\begin{array}{l}\text { I: } 44 \%(95 \% \text { CI } 31 \%-49 \%) \\
\text { II: } 32 \%(95 \% \text { CI } 19 \%-45 \%)\end{array}$ & $\begin{array}{l}\text { I: } 36 \%(95 \% \text { CI } 18 \%-54 \%) \\
\text { II: } 24 \%(95 \% \text { CI } 9 \%-38 \%)\end{array}$ \\
\hline Manchikanti et al (78) 2001 & $\mathrm{~L}$ & $\begin{array}{l}\text { Gp I }(B M I<30)=50 \\
\text { Gp II }(B M I \geq 30)=50\end{array}$ & $\mathrm{P}$ & $\begin{array}{l}\text { I: } 36 \%(95 \% \text { CI } 22 \%-50 \%) \\
\text { II: } 40 \% \text { (95\% CI } 26 \%-54 \%)\end{array}$ & $\begin{array}{l}\text { I: } 44 \% \text { (95\% CI } 26 \%-61 \%) \\
\text { II: } 33 \%(95 \% \text { CI } 16 \%-51 \%)\end{array}$ \\
\hline Manchikanti et al (39) 2002 & $\mathrm{~L}$ & 120 & $\mathrm{P}$ & $40 \%$ (95\% CI $31 \%-49 \%)$ & $30 \%(95 \%$ CI $20 \%-40 \%)$ \\
\hline Manchikanti et al (38) 2003 & $\mathrm{~L}$ & $\begin{array}{l}\text { GI: Single region }=150 \\
\text { GII: multiple regions }=150\end{array}$ & $\mathrm{P}$ & $\begin{array}{l}\text { I: } 21 \%(95 \% \text { CI } 14 \%-27 \%) \\
\text { II : } 41 \%(95 \% \text { CI } 33 \%-49 \%)\end{array}$ & $\begin{array}{l}\text { I: } 17 \%(95 \% \text { CI } 10 \%-24 \%) \\
\text { II : } 27 \%(95 \% \text { CI } 18 \%-36 \%)\end{array}$ \\
\hline Manchikanti et al (40) 2004 & $\mathrm{~L}$ & 397 of 500 patients & $\mathrm{P}$ & $31 \%(95 \%$ CI $27 \%-36 \%)$ & $27 \%(95 \%$ CI $22 \%-32 \%)$ \\
\hline
\end{tabular}

$\mathrm{C}=$ Cervical; $\mathrm{T}=$ Thoracic; $\mathrm{L}=$ Lumbar; RCT: Randomized Controlled Trial; $\mathrm{P}=$ prospective; $\mathrm{RA}=$ randomized; $\mathrm{PC}=$ placebo controlled; $\mathrm{DB}=$ double blind; $\mathrm{NA}=$ not available

joint/nerves selectively and accurately under fluoroscopic visualization; physiologic assessment of evoked pain and analgesic responses; and finally, these blocks can be submitted to critical appraisal in multiple controlled trials. Provocation of pain, however, is considered to be ineffective in evaluating facet joint pain (104), although it may be of value for other structures. These blocks have been critically evaluated in multiple controlled trials, as well in a previous systematic review, and multiple systematic analyses. Consequently, the patient and physician can be assured that the validity of the test is maintained in the majority of the patients when proper technique and selection criteria are employed.

This systematic review shows that controlled comparative local anesthetic or placebo-controlled diagnostic facet joint blocks are safe, accurate and provide reproducible results, whereas single uncontrolled blocks are unreliable.

\section{CONCLUSION}

Diagnostic facet joint blocks are safe, valid and reliable. Based on review of available studies that met inclusion criteria, there is strong evidence that controlled diagnostic blocks reliably distinguish painful from painless facet joints. This diagnostic information is useful in the management of chronic spinal pain.

\section{ACKNOWLEDGEMENTS}

The authors wish to thank the editors of Pain Physician for peer review and constructive criticism, which ultimately improved the quality and understanding of the manuscript. 
Appendix A. Domains for diagnostic studies developed by the Agency for Healthcare Research and Quality (AHRQ) (92)

Key domains are in italics

Study Population

Adequate Description of Test

Appropriate Reference Standard

Blinded Comparison of Test and Ref-

erence

Avoidance of Verification Bias

Appendix B. Elements for diagnostic studies developed by the Agency for Healthcare Research and Quality (AHRQ) (92)

Elements appearing in italics are those with an empirical basis. Elements appearing in bold are those considered essential to give a system a Yes rating for the domain.

- Subjects similar to populations in which the test would be used and with a similar spectrum of disease

- Details of test and its administration sufficient to allow for replication of study

- $\quad$ Appropriate reference standard ("gold standard") used for comparison

- Reference standard reproducible

- Evaluation of test without knowledge of disease status, if possible

- Independent, blind interpretation of test and reference

- Decision to perform reference standard not dependent on results of test under study
Appendix C. Items utilized for assessment of quality of individual articles of diagnostic studies by QUADAS tool (93)

1. Was the spectrum of patients representative of the patients who will receive the test in practice?

2. Were selection criteria clearly described?

3. Is the reference standard likely to correctly classify the target condition?

4. Is the time period between reference standard and index test short enough to be reasonably sure that the target condition did not change between the two tests?

5. Did the whole sample or a random selection of the sample, receive verification using a reference standard of diagnosis?

6. Did patients receive the same reference standard regardless of the index test result?

7. Was the reference standard independent of the index test (i.e. the index test did not form part of the reference standard)?

8. Was the execution of the index test described in sufficient detail to permit replication of the test?

9. Was the execution of the reference standard described in sufficient detail to permit its replication?

10. Were the index test results interpreted without knowledge of the results of the reference standard?

11. Were the reference standard results interpreted without knowledge of the results of the index test?

12. Were the same clinical data available when test results were interpreted as would be available when the test is used in practice?

13. Were uninterpretable/intermediate test results reported?

14. Were withdrawals from the study explained?

\section{Author AfFiliation}

Nalini Sehgal, MD

Medical Director

UW Interventional Pain

Program

University of Wisconsin

Medical School

Dept, of Orthopedics and

Rehabillitation

600 Highland Avenue, \#2424

Madison, WI 53792

E-mail: n.sehgal@hosp.wisc.edu

Rinoo V. Shah, MD

Assistant Professor

Pain Fellowship Director

Interventional Pain Institute

Texas Tech University Health Sciences

Center

4430 South Loop 289

Lubbock, TX 79414

E-mail: rinoo_shah@yahoo.com

Anne Marie McKenzie-Brown, MD

Assistant Professor of Anesthesiology

Division Director, Division of Pain

Medicine

Emory Department of Anesthesiology

Emory Center for Pain Medicine

550 Peachtree Street, NE

Atlanta, GA 30308

E-mail: anne_marie_mckenzie-

brown@emory.org

\section{Clifford R. Everett, MD}

Assistant Professor,

Department of Orthopaedics

and Physical Medicine and

Rehabilitation

University of Rochester Medical Center

601 Elmwood Avenue, Box 65

Rochester, NY 14642

E-mail: clifford_everett@URMC.Roche

ster.edu

\section{RefERENCES}

1. Lawrence RC, Helmick CG, Arnett FC. Estimates of the prevalence of arthritis and selected musculoskeletal disorders in the United States. Arthritis Rheum 1998; 41: 778-799.

2. Manchikanti L, Staats PS, Singh V, Schultz DM, Vilims BD, Jasper JF, Kloth DS, Trescot AM, Hansen HC, Falasca TD, Racz GB, Deer T, Burton AW, Helm S, Lou L, Bakhit CE, Dunbar EE, Atluri SL, Calodney AK, Hassenbusch S, Feler CA. Evidence-based practice guidelines for interventional techniques in the management of chronic spinal pain. Pain Physician 2003; 6:3-80. 
3. Linton SJ, Hellsing AL, Hallden K. A population based study of spinal pain among 35-45-year-old individuals. Spine 1998; 23:1457-1463.

4. Manchikanti L, Pampati VS. Research designs in interventional pain management: Is randomization superior, desirable or essential? Pain Physician 2002; 5:275-284.

5. Deyo RA, Weinstein JN. Low back pain. $N$ Engl J Med 2001; 344:363-370.

6. Kirwan EO. Back pain. In Wall PD, Melzack R (eds.) Textbook of Pain, $2^{\text {nd }}$ ed. Churchill Livingstone, Edinburgh, 1989, pp 335340.

7. Deyo RA, Rainville J, Kent DL. What can the history and physical examination tell us about low back pain? JAMA 1992; 268: 760-765.

8. Bogduk N, McGuirk B. Causes and sources of chronic low back pain. In Bogduk N, McGuirk B (eds). Medical Management of Acute and Chronic Low Back Pain. An Evidence-Based Approach: Pain Research and Clinical Management. Elsevier Science BV, Amsterdam, 2002; 13:pp 115126.

9. Bogduk N, McGuirk B. An algorithm for precision diagnosis. In Bogduk N, McGuirk B (eds.) Medical Management of Acute and Chronic Low Back Pain. An Evidence-Based Approach: Pain Research and Clinical Management. Elsevier Science BV, Amsterdam, 2002; 13: pp 177186.

10. Bogduk N. Low back pain. In Clinical Anatomy of the Lumbar Spine and Sacrum, 3rd ed. Churchill Livingstone, New York, 1997, pp 187-214.

11. Bogduk N. The clinical anatomy of the cervical dorsal rami. Spine 1982; 7:319-330.

12. Chua WH, Bogduk N. The surgical anatomy of thoracic facet denervation. Acta Neurochir (Wien) 1995; 136:140-144.

13. Bogduk N, Wilson AS, Tynan W. The human lumbar dorsal rami. J Anat 1982; 134: 383-397.

14. Stilwell DL. The nerve supply of the vertebral column and its associated structures in the monkey. Anat Rec 1956; 125:139169.

15. Cavanaugh JM, Ozaktay AC, Yamashita HT, King Al. Lumbar facet pain: Biomechanics, neuroanatomy, and neurophysiology. J Biomech 1996; 29:1117-1129.

16. Fukui S, Ohseto K, Shiotani M, Ohno K, Karasawa H, Naganuma Y, Yuda Y. Referred pain distribution of the cervical zyg apophysial joints and cervical dorsal rami. Pain 1996; 68:79-83.

17. Dwyer A, Aprill C, Bogduk N. Cervical zygapophysial joint pain patterns. I: A study in normal volunteers. Spine 1990; 6:453457.

18. Aprill C, Dwyer A, Bogduk N. The prevalence of cervical zygapophysial joint pain patterns. II: A clinical evaluation. Spine 1990; 6:458-461.

19. Pawl RP. Headache, cervical spondylo- sis, and anterior cervical fusion. Surg Ann 1977; 9:391-408.

20. Dreyfuss P, Tibiletti C, Dreyer SJ. Thoracic zygapophysial joint pain patterns: A study in normal volunteers. Spine 1994; 19:807811.

21. Mooney V, Robertson J. The facet syndrome. Clin Orthop 1976; 115:149-156.

22. McCall IW, Park WM, O'Brien JP. Induced pain referral from posterior elements in normal subjects. Spine 1979; 4:441-446.

23. Marks R. Distribution of pain provoked from lumbar facet joints and related structures during diagnostic spinal infiltration. Pain 1989; 39:37-40.

24. Fukui S, Ohseto $\mathrm{K}$, Shiotani $M$, Ohno K, Karasawa H, Naganuma Y. Distribution of referral pain from the lumbar zygapophysial joints and dorsal rami. Clin J Pain 1997; 13:303-307.

25. Hirsch C, Ingelmark BE, Miller M. The anatomical basis for low back pain. Acta Orthop Scand 1963; 33:1-17.

26. Windsor RE, King FJ, Roman SJ, Tata NS, Cone-Sullivan LA, Thampi S, Acebey M, Gilhool JJ, Rao R, Sugar R. Electrical stimulation induced lumbar medial branch referral patterns. Pain Physician 2002; 5 : 347-353.

27. Bogduk N. International Spinal Injection Society guidelines for the performance of spinal injection procedures. Part 1: Zygapophysial joint blocks. Clin J Pain 1997; 13:285-302.

28. Boswell MV, Singh V, Staats PS, Hirsch JA. Accuracy of precision diagnostic blocks in the diagnosis of chronic spinal pain of facet or zygapophysial joint origin. Pain Physician 2003; 6:449-456.

29. Bogduk N, Lord S. Cervical zygapophysial joint pain. Neurosurgery 1998; 8:107-117.

30. Barnsley L, Lord S, Bogduk N. Comparative local anesthetic blocks in the diagno sis of cervical zygapophysial joints pain. Pain 1993; 55:99-106.

31. Lord SM, Barnsley L, Bogduk N. The utility of comparative local anesthetic blocks versus placebo-controlled blocks for the diagnosis of cervical zygapophysial joint pain. Clin J Pain 1995; 11:208-213.

32. Schwarzer AC, Aprill CN, Derby R, Fortin J, Kine G, Bogduk N. Clinical features of patients with pain stemming from the lumbar zygapophysial joints. Is the lumbar facet syndrome a clinical entity? Spine 1994; 19:1132-1137.

33. Manchikanti L, Pampati VS, Fellows B, Pakanati RR. Prevalence of lumbar facet joint pain in chronic low back pain. Pain Physician 1999; 2:59-64.

34. Manchikanti L, Pampati VS, Fellows B, Baha A. The inability of the clinical picture to characterize pain from facet joints. Pain Physician 2000; 3:158-166.

35. Manchikanti L, Pampati VS, Fellows B, Bakhit $C$. The diagnostic validity and therapeutic value of medial branch blocks with or without adjuvants. Curr Rev Pain 2000;
4:337-344.

36. Schwarzer AC, Wang SC, Bogduk N, MCNaught PJ, Laurent R. Prevalence and clinical features of lumbar zygapophysial joint pain: A study in an Australian population with chronic low back pain. Ann Rheum Dis 1995; 54:100-106.

37. Manchikanti L, Singh V, Pampati VS, Damron K, Barnhill R, Beyer C, Cash K. Evaluation of the relative contributions of various structures in chronic low back pain. Pain Physician 2001; 4:308-316.

38. Manchikanti L, Hirsch JA, Pampati VS. Chronic low back pain of facet (zygapophysial) joint origin: Is there a difference based on involvement of single or multiple spinal regions? Pain Physician 2003; 6:399-405.

39. Manchikanti L, Singh V, Pampati VS, Damron K, Beyer C, Barnhill R. Is there correlation of facet joint pain in lumbar and cervical spine? An evaluation of prevalence in combined chronic low back and neck pain. Pain Physician 2002; 5:365-371.

40. Manchikanti L, Boswell MV, Singh V, Pampati VS, Damron KS, Beyer CD. Prevalence of facet joint pain in chronic spinal pain of cervical, thoracic, and lumbar regions. BMC Musculoskelet Disord 2004; 5:15.

41. Manchikanti L, Singh V, Pampati VS, Beyer C, Damron K. Evaluation of the prevalence of facet joint pain in chronic thoracic pain. Pain Physician 2002; 5:354-359.

42. Barnsley L, Lord SM, Wallis BJ, Bogduk $\mathrm{N}$. The prevalence of chronic cervical zygapophysial joint pain after whiplash. Spine 1995; 20:20-26.

43. Lord SM, Barnsley L, Wallis BJ, Bogduk N. Chronic cervical zygapophysial joint pain with whiplash: A placebo-controlled prevalence study. Spine 1996; 21:1737-1745.

44. Manchikanti L, Singh V, Rivera J, Pampati VS. Prevalence of cervical facet joint pain in chronic neck pain. Pain Physician 2002; 5:243-249.

45. Bogduk N, McGuirk B. Precision diagnosis. In Medical Management of Acute and Chronic Low Back Pain. An EvidenceBased Approach: Pain Research and Clinical Management. Elsevier Science BV, Amsterdam, 2002; 13: pp 169-176.

46. Bogduk N, McGuirk B. Assessment. In Medical Management of Acute and Chronic Low Back Pain. An Evidence-Based Approach: Pain Research and Clinical Management. Elsevier Science BV, Amsterdam, 2002; 13: pp 127-138.

47. Helbig T, Lee CK. The lumbar facet syndrome. Spine 1988; 13:61-64.

48. Fairbank JCT, Park WM, McCall IW, O’Brien JP. Apophyseal injection of local anesthetic as a diagnostic aid in primary low back pain syndromes. Spine 1981; 6:598-605.

49. Schwarzer AC, Scott AM, Wang SC, Hoschl R, Wiseman JC, Copper RA. The role of bone scintigraphy in chronic low back pain: A comparison of SPECT and planar images and zygapophysial joint injection. Aust NZJ Med 1992; 22:185. 
50. Raymond J, Dumas JM. Intraarticular facet block: Diagnostic tests or therapeutic procedure? Radiology 1989; 151:333-336.

51. Schwarzer AC, Derby R, Aprill CN, Fortin J, Kine G, Bogduk N. Pain from the lumbar zygapophysial joints: A test of two models. J Spinal Disord 1994; 7:331-336.

52. Jackson RP, Jacobs RR, Montesano PX. Facet joint injection in low back pain. A prospective statistical study. Spine 1988; 13:966-971.

53. Jackson RP. The facet syndrome: Myth or reality? Clin Orthop 1992; 279:110-121.

54. Jonsson H, Bring G, Rauschning W, Sahlstedt B. Hidden cervical spine injuries in traffic accident victims with skull fractures. J Spinal Dis 1991; 4:251-263.

55. Taylor JR, Twomey LT. Acute injuries to cervical joints: An autopsy study of neck sprain. Spine 1993; 9:1115-1122.

56. Schwarzer AC, Wang SC, O’Driscoll D, Harrington T, Bogduk N, Laurent R. The ability of computed tomography to identify a painful zygapophysial joint in patients with chronic low back pain. Spine 1995; 20:907-912.

57. Binet EF, Moro JJ, Marangola JP, Hodge C). Cervical spine tomography in trauma. Spine 1977; 2:163-172.

58. Abel MS. Occult traumatic lesions of the cervical vertebrae. Critical Rev Clin Radiol Nuclear Med 1975; 6:469-553.

59. Woodring JH, Goldstein SJ. Fractures of the articular processes of the cervical spine. Am J Roentgenol 1982; 139:341344 .

6o. Magora A, Bigos SJ, Stolov WC, Tomsli MA, Magora F, Vatine JJ. The significance of medical imaging findings in low back pain. Pain Clinic 1994; 7:99-105.

61. Murtagh FR. Computed tomography and fluoroscopy guided anesthesia and steroid injection in facet syndrome. Spine 1988; 13:686-689.

62. Faye LJ, Wiles MR. Manual examination of the spine. In Haldeman S (ed). Principles and Practice of Chiropractic. $2^{\text {nd }}$ ed. Appleton \& Lange, San Mateo, 1992, pp 301318.

63. Destouet JM, Gilula LA, Murphy WA, Monsees $B$. Lumbar facet joint injection: Indication, technique, clinical correlation and preliminary results. Radiology 1982; 145: 321-325.

64. Moran R, O'Connell D, Walsh MG. The diagnostic value of facet joint injections. Spine 1988; 13:1407-1410.

65. Dory MA. Arthrography of the cervical facet joints. Radiology 1983; 148:379-382.

66. Dory MA. Arthrography of the lumbar facet joints. Radiology 1981; 140:23-27.

67. Revel ME, Listrat VM, Chevalier XJ, Dougados M, N'guyen MP, Vallee C, Wybier M, Gires F, Amor B. Facet joint block for low back pain: Identifying predictors of a good response. Arch Phys Med Rehabil 1992; 73:824-828.

68. Revel M, Poiraudeau S, Auleley GR, Pay- an C, Denke A, Nguyen M, Chevrot A, Fermanian J. Capacity of the clinical picture to characterize low back pain relieved by facet joint anesthesia. Proposed criteria to identify patients with painful facet joints. Spine 1998; 23:1972-1977.

69. Laslett M, Oberg B, Aprill CN, McDonald B. Zygapophysial joint blocks in chronic low back pain: a test of Revel's model as a screening test. BMC Musculoskelet Disord 2004; 5:43.

70. Young S, Aprill C, Laslett M. Correlation of clinical examination characteristics with three sources of chronic low back pain. Spine J 2003; 3:460-465.

71. North RB, Kidd DH, Zahurak M, Piantadosi S. Specificity of diagnostic nerve blocks: A prospective, randomized study of sciatica due to lumbosacral spine disease. Pain 1996; 65:77-85.

72. Hogan QH, Abram SE. Neural blockade for diagnosis and prognosis. Anesthesiology 1997; 86:216-241.

73. Hildebrandt J. Relevance of nerve blocks in treating and diagnosing low back pain is the quality decisive? Schmerz 2001; 15: 474-483.

74. Saal JS. General principles of diagnostic testing as related to painful lumbar spine disorders. Spine 2002; 27:2538-2545.

75. Barnsley L, Lord S, Wallis B, Bogduk N. False-positive rates of cervical zygapophysial joint blocks. Clin J Pain 1993; 9:124130.

76. Manchikanti L, Pampati VS, Rivera J, Fellows B, Beyer C, Damron K. Role of facet joints in chronic low back pain in the elderly: A controlled comparative prevalence study. Pain Practice 2001; 1:332-337.

77. Manchikanti L, Pampati VS, Baha A, Fellows B, Damron KS, Barnhill RC. Contribution of facet joints to chronic low back pain in postlumbar laminectomy syndrome: A controlled comparative prevalence evaluation. Pain Physician 2001; 4:175-180.

78. Manchikanti L, Pampati VS, Singh V, Beyer CD, Damron KS, Fellows B. Evaluation of the role of facet joints in persistent low back pain in obesity: A controlled, prospective, comparative evaluation. Pain Physician 2001; 4:266-272.

79. Schwarzer AC, Aprill CN, Derby R, Fortin J, Kine G, Bogduk N. The false-positive rate of uncontrolled diagnostic blocks of the lumbar zygapophysial joints. Pain 1994; 58:195-200.

8o. Ackerman WE, Munir MA, Zhang JM, Ghaleb A. Are diagnostic lumbar facet injections influenced by pain of muscular origin? Pain Practice 2004; 4:286-291.

81. Bogduk N, McGuirk B. Precision treatment. In Bogduk N, McGuirk B (eds). Medical Management of Acute and Chronic Low Back Pain. An Evidence-Based Approach: Pain Research and Clinical Management, Vol. 13, Elsevier Science BV, Amsterdam, 2002, pp 187-198.

82. Bogduk N, McGuirk B. An approach to chronic low back pain. In Bogduk N, Mc-
Guirk B (eds). Medical Management of Acute and Chronic Low Back Pain. An Evidence-Based Approach: Pain Research and Clinical Management, Vol. 13, Elsevier Science BV, Amsterdam, 2002, pp 199204 .

83. Nachemson A, Vingård E. Assessment of patients with neck and back pain: $A$ bestevidence synthesis. In Nachemson A, Vingård E (eds). Neck and back pain. The scientific evidence of causes, diagnosis and treatment. Lippincott Williams \& Wilkins, Philadelphia, 2000, pp 189-236.

84. Ramsey SD, Luce BR, Deyo R, Franklin G. The limited state of technology assessment for medical devices: Facing the issues. Am J Managed Care 1998; 4:188199.

85. Merskey H, Bogduk N. Classification of chronic pain. In Descriptions of Chronic Pain Syndromes and Definition of Pain Terms, $2^{\text {nd }}$ ed. IASP Press, Seattle, 1994, pp 180-181.

86. Dreyfuss P, Schwarzer AC, Lau P, Bogduk N. Specificity of lumbar medial branch and L5 dorsal ramus blocks. Spine 1997; 22:895-902.

87. Barnsley L, Bogduk N. Medial branch blocks are specific for the diagnosis of cervical zygapophysial joint pain. Reg Anesth 1993; 18:343-350.

88. Kaplan M, Dreyfuss P, Halbrook B, Bogduk $N$. The ability of lumbar medial branch blocks to anesthetize the zygapophysial joint. Spine 1998; 23:1847-1852.

89. Bonica JJ. Local anesthesia and regional blocks. In Wall PD, Melzack R (eds). Textbook of Pain, $2^{\text {nd }}$ ed. Churchill Livingstone, Edinburgh, 1989, pp 724-743.

90. Bonica JJ, Buckley FP. Regional analgesia with local anesthetics. In Bonica JJ (ed). The Management of Pain. Lea \& Febiger, Philadelphia, 1990; 2:1883-1966.

91. Boas RA. Nerve blocks in the diagnosis of low back pain. Neurosurg Clin North Am 1991; 2:806-816.

92. West S, King V, Carey T, Lohr K, McKoy $\mathrm{N}$, Sutton S, Lux L. Systems to rate the strength of scientific evidence. Evidence Report/Technology Assessment No. 47 University of North Carolina: Agency for Healthcare Research and Quality. AHRQ Publication No. 02-Eo16; April 2002.

93. Whiting P, Rutjes A, Reitsma J, Bossuyt P, Kleijnen J. The Development of QUADAS: A tools for the quality assessment of studies of diagnostic accuracy included in systematic reviews. BMC Med Res Methodol 2003; 3:25.

94. Manchikanti L, Pampati VS, Bakhit CE, Rivera J), Beyer CD, Damron KS, Barnhill RC. Effectiveness of lumbar facet joint nerve blocks in chronic low back pain: A randomized clinical trial. Pain Physician 2001; 4: 101-117.

95. Manchikanti KN, Pampati VS, Damron KS, McManus CD. A double-blind, controlled evaluation of the value of Sarapin in neural blockade. Pain Physician 2004; 7:59-62. 
96. Manchikanti L, Manchikanti KN, Damron KS, Pampati VS. Effectiveness of cervical medial branch blocks in chronic neck pain: A prospective outcome study. Pain Physician 2004; 7:195-202.

97. Manchikanti L, Singh V, Pampati VS. Are diagnostic lumbar medial branch blocks valid? Results of 2-year follow-up. Pain Physician 2003; 5:147-153.

98. Manchikanti L, Pampati VS, Fellows B, Rivera JJ, Damron KS, Beyer CD. Influence of psychological factors on the ability of diagnose chronic low back pain of facet joint origin. Pain Physician 2001; 4:349-357.

99. Manchikanti L, Pampati VS, Damron KS, MCManus CD, Jackson SD, Barnhill RC, Martin JC. A randomized, prospective, double-blind, placebo-controlled evaluation of the effect of sedation on diagnostic validity of cervical facet joint pain. Pain Physician 2004; 7:301-310.
100. Manchikanti L, Damron KS, Rivera J, McManus CD, Jackson SD, Barnhill RC, Martin JC. Evaluation of effect of sedation as a confounding factor in the diagnostic validity of lumbar facet joint pain: A prospective, randomized, double-blind, placebo-controlled evaluation. Pain Physician 2004; 7:411-417.

101. Schwarzer AC, Aprill CN, Derby R, Fortin J, Kine $\mathrm{G}$, Bogduk N. The relative contributions of the disc and zygapophysial joint in chronic low back pain. Spine 1994; 19: 801-806.

102. Manchikanti L, Singh V, Fellows B, Pampati VS. Evaluation of influence of gender, occupational injury, and smoking on chronic low back pain of facet joint origin: A subgroup analysis. Pain Physician 2002; 5 : 30-35.

103. Bogduk N, Marsland A. On the concept of third occipital headache. J Neurol Neuro- surg Psychiatry 1986; 49:775-780.

104. Schwarzer AC, Derby R, Aprill CN, Fortin J, Kine G, Bogduk N. The value of the provocation response in lumbar zygapophysia joint injections. Clin J Pain 1994; 10:309313.

105. Speldewinde GC, Bashford GM, Davidson IR. Diagnostic cervical zygapophysial joint blocks for chronic cervical pain. Med J Aust 2001; 174:174-176.

106. Jaeschke R, Guyatt G, Lijmer J. Diagnostic tests. In Guyatt G, Rennie D (eds). Users' Guides to the Medical Literature - A Manual for Evidence-Based Clinical Practice. AMA Press, Chicago, 2002, pp 121-140.

107. Sackett DL, Haynes RB, Guyatt GH, Tugwell P. Clinical Epidemiology, A Basic Science for Clinical Medicine. 2nd ed. Little, Brown and Company, Boston, 1991, pp 5357. 